\title{
Cell-Type-Specific Modulation of Sensory Responses in Olfactory Bulb Circuits by Serotonergic Projections from the Raphe Nuclei
}

\author{
Daniela Brunert, ${ }^{1,2} \odot$ Y usuke Tsuno, ${ }^{1}$ Markus Rothermel, ${ }^{1,2}{ }^{\oplus}$ Michael T. Shipley, ${ }^{3}$ and Matt Wachowiak ${ }^{1}$ \\ ${ }^{1}$ Department of Neurobiology and Anatomy, University of Utah, Salt Lake City, Utah 84112, ${ }^{2}$ Department of Chemosensation, Institute for Biology II, \\ RWTH Aachen University, 52056 Aachen, Germany, and 3Department of Anatomy and Neurobiology, University of Maryland School of Medicine, \\ Baltimore, Maryland 21201
}

Serotonergic neurons in the brainstem raphe nuclei densely innervate the olfactory bulb (OB), where they can modulate the initial representation and processing of olfactory information. Serotonergic modulation of sensory responses among defined $\mathrm{OB}$ cell types is poorly characterized in vivo. Here, we used cell-type-specific expression of optical reporters to visualize how raphe stimulation alters sensory responses in two classes of GABAergic neurons of the mouse $\mathrm{OB}$ glomerular layer, periglomerular (PG) and short axon (SA) cells, as well as mitral/tufted (MT) cells carrying OB output to piriform cortex. In PG and SA cells, brief $(1-4 \mathrm{~s})$ raphe stimulation elicited a large increase in the magnitude of responses linked to inhalation of ambient air, as well as modest increases in the magnitude of odorantevoked responses. Near-identical effects were observed when the optical reporter of glutamatergic transmission iGluSnFR was expressed in PG and SA cells, suggesting enhanced excitatory input to these neurons. In contrast, in MT cells imaged from the dorsal OB, raphe stimulation elicited a strong increase in resting GCaMP fluorescence with only a slight enhancement of inhalation-linked responses to odorant. Finally, optogenetically stimulating raphe serotonergic afferents in the OB had heterogeneous effects on presumptive MT cells recorded extracellularly, with an overall modest increase in resting and odorant-evoked responses during serotonergic afferent stimulation. These results suggest that serotonergic afferents from raphe dynamically modulate olfactory processing through distinct effects on multiple $\mathrm{OB}$ targets, and may alter the degree to which $\mathrm{OB}$ output is shaped by inhibition during behavior.

Key words: imaging; inhibition; neuromodulation; optogenetics; serotonin; sniffing

Significance Statement

Modulation of the circuits that process sensory information can profoundly impact how information about the external world is represented and perceived. This study investigates how the serotonergic system modulates the initial processing of olfactory information by the olfactory bulb, an obligatory relay between sensory neurons and cortex. We find that serotonergic projections from the raphe nuclei to the olfactory bulb dramatically enhance the responses of two classes of inhibitory interneurons to sensory input, that this effect is mediated by increased glutamatergic drive onto these neurons, and that serotonergic afferent activation alters the responses of olfactory bulb output neurons in vivo. These results elucidate pathways by which neuromodulatory systems can dynamically regulate brain circuits during behavior.

\section{Introduction}

Neuromodulation of sensory circuits can shape neural representations of sensory information and thus impact sensory percep-

\footnotetext{
Received 0ct. 5, 2015; revised April 8, 2016; accepted May 17, 2016.

Author contributions: D.B., Y.T., M.R., M.T.S., and M.W. designed research; D.B., Y.T., M.R., and M.W. performed research; D.B., Y.T., and M.W. analyzed data; D.B. and M.W. wrote the paper.

This work was supported by funding from NIH (DC012718) and from the Deutsche Forschungsgemeinschaft (R04046/2-1, Emmy Noether Program to M.R.). We thank C. Zabawa and J. Ball for technical support, A. Moran for contributing data to the iGluSnFR characterization, J. Brill, A. Puche and I. Youngstrom for helpful comments on the paper, as well as Drs. Looger, Akerboom, and Kim and the Genetically Encoded Calcium Indicator (GECI) Project at Janelia Farm Research Campus in collaboration with Penn Vector Core for providing with GCaMP-expressing viruses.
}

tion dependent on brain and behavioral state. In the olfactory system, incoming information from primary sensory neurons is subject to modulation by multiple neuromodulatory systems that include cholinergic, noradrenergic, and serotonergic fibers targeting circuits of the olfactory bulb $(\mathrm{OB})$ at the first stage of olfactory information processing. Though numerous studies

Correspondence should be addressed to Dr. Matt Wachowiak, Department of Neurobiology and Anatomy, University of Utah, 36 South Wasatch Drive, Salt Lake City, UT 84112. E-mail: matt.wachowiak@utah.edu.

DOI:10.1523/JNEUROSCI.3667-15.2016

Copyright $\odot 2016$ the authors $\quad 0270-6474 / 16 / 366820-16 \$ 15.00 / 0$ 
have described $\mathrm{OB}$ neuromodulation by cholinergic (Ichikawa and Hirata, 1986; Ojima et al., 1988; Nunez-Parra et al., 2013; Rothermel et al., 2014; Liu et al., 2015) and noradrenergic systems (Shipley et al., 1985; McLean et al., 1989; Shea et al., 2008), serotonergic modulation of $\mathrm{OB}$ circuits has been less well characterized, especially with respect to its impact on sensory responses in vivo (Petzold et al., 2009; Kapoor et al., 2016).

Ascending serotonergic projections originate in the dorsal raphe nuclei (DRN) and median raphe nuclei (MRN) and innervate structures throughout the telencephalon, as well as thalamus (Jacobs and Azmitia, 1992). The activity of serotonergic raphe neurons changes with the sleep-wake cycle and alertness (Monti, 2011; Zeitzer, 2013), as well as during voluntary motor output and specific epochs of reward-conditioned behaviors (Jacobs and Fornal, 1997; Ranade and Mainen, 2009; Hurley and Sullivan, 2012). One hypothesized function of the serotonergic system is to facilitate motor output and simultaneously suppress processing of sensory inputs (Jacobs and Fornal, 1999; Hurley et al., 2004). Serotonergic activation suppresses neural and/or behavioral sensory responses in multiple sensory modalities (Dugué et al., 2014). Other studies, however, have shown that serotonin can have a more nuanced impact on sensory responses through distinct effects on different cell types within central processing networks (Xiang and Prince, 2003; Hurley et al., 2004; Moreau et al., 2010; Hurley and Sullivan, 2012; Enger et al., 2015).

Consistent with this view, serotonergic inputs to the $\mathrm{OB}$ target multiple elements of OB circuitry. Serotonergic projections from the dorsal and median raphe innervate all layers of the $\mathrm{OB}$ (McLean and Shipley, 1987; Steinfeld et al., 2015). In vitro studies have provided evidence for direct actions of serotonin on glutamatergic neurons including external tufted (ET) cells and mitral/ tufted (MT) cells (Liu et al., 2012; Kapoor et al., 2016), as well as on at least some GABAergic interneurons in the glomerular layer (Hardy et al., 2005; Liu et al., 2012; Schmidt and Strowbridge, 2014; Brill et al., 2016). However, how serotonergic afferents modulate sensory-evoked responses of different $\mathrm{OB}$ neurons in vivo remains unclear. Prolonged activation of raphe afferents has been reported to suppress olfactory sensory neuron (OSN) input and activate a subpopulation of juxtaglomerular neurons (Petzold et al., 2009), and brief activation of these afferents was recently shown to differentially modulate the excitability of $\mathrm{OB}$ mitral versus tufted cells (Kapoor et al., 2016). Raphe modulation of other OB circuit elements has not been characterized in vivo.

Here, we examined the effect of serotonergic raphe modulation on sensory responses of distinct cell types in the OB, including GAD65-expressing periglomerular (PG) cells, tyrosine hydroxylase (TH)-expressing short axon (SA) cells and MT cells, using a combination of cell-type-specific GCaMP imaging, optogenetic activation of serotonergic fibers and single-unit extracellular recordings. We also used a recently developed optical reporter of glutamate signaling (Marvin et al., 2013) to identify raphe effects presynaptic to PG and SA cells. We found that briefly activating $\mathrm{OB}$ inputs from the raphe strongly enhances the responsiveness of PG and SA cells to inhalation of ambient air and modestly enhances responses to odorant inhalation; we further found that this enhancement is largely attributable to increased glutamatergic input to these neurons. Raphe has more heterogeneous effects on MT cells, with modulation varying across individual neurons and which do not manifest as increased inhalation patterning across the MT population. These results suggest that afferents from raphe dynamically regulate olfactory processing through multiple $\mathrm{OB}$ targets, and may alter the degree to which $\mathrm{OB}$ output is shaped by inhibition during behavior.

\section{Materials and Methods}

Animals. Experiments were performed on male and female transgenic mice expressing Cre recombinase (Cre) in defined neuronal populations, and in some experiments, crossed with the Ai38 Rosa-GCaMP3 reporter line (Zariwala et al., 2012), the Ai9 Rosa-tdTomato reporter line (Madisen et al., 2010) or the Ai95D Rosa-GCaMP6f reporter line (Chen et al., 2013). Mouse strains used were as follows: GAD2-IRES-Cre (Taniguchi et al., 2011), Jax Stock \#010802; TH-Cre, Jax Stock \#008601; PCdh21-Cre (Nagai et al., 2005; Gong et al., 2007), MMRRC Stock \#030952-UCD; Slc6a4-Cre (Gong et al., 2007), MMRRC Stock \#031028-UCD; Ai38 (Zariwala et al., 2012), Jax Stock \# 014538; Ai9 (Madisen et al., 2010), Jax Stock \#007905, and Ai95D, Jax Stock \#024105. Mice ranged in age from 3-7 months. Mice were housed up to 5/cage and kept on a $12 \mathrm{~h} \mathrm{light/dark}$ cycle with food and water available ad libitum. All procedures were performed following the National Institutes of Health Guide for the Care and Use of Laboratory Animals and were approved by the University of Utah Institutional Animal Care and Use Committee.

Viral vector expression. Viral vectors driving Cre-dependent expression of GCaMP3 (Tian et al., 2009), GCaMP5G (Akerboom et al., 2012), GCAMP6f (Chen et al., 2013), iGluSnFR (Marvin et al., 2013), and hChR2-eYFP were obtained from the University of Pennsylvania Vector Core (AAV1, 5 or 9 serotype) and injected either into the dorsal OB, anterior piriform cortex (aPC) or the dorsal raphe nuclei (DRN), as specified in the Results. For injection, mice were anesthetized with ketamine $(70 \mathrm{mg} / \mathrm{kg})$ and medetomidine $(1 \mathrm{mg} / \mathrm{kg}$; Domitor, Pfizer $)$ or isoflurane $(0.5-2 \%)$, placed in a stereotaxic head-holder and a circular craniotomy $(0.1 \sim 0.5 \mathrm{~mm})$ was made over the injection site. Dorsal OB injections were performed using glass pipettes lowered to a depth of $200-350 \mu \mathrm{m}$; deep brain injections used 33 gauge metal needles positioned at the following stereotaxic coordinates (millimeters relative to bregma): aPC: $2.34 \mathrm{AP},+1.5 \mathrm{LM},-3.125 \mathrm{DV}$; DRN: $-4.1 \mathrm{AP}, 0 \mathrm{LM}$, $-2.8 \mathrm{DV}$. Virus was injected using a programmable syringe controller (QSI, Stoelting) or a picospritzer at a rate of $0.1 \mu \mathrm{l} / \mathrm{min}(0.1-0.5 \mu \mathrm{l}$ for OB injections; $0.5-1.0 \mu \mathrm{l}$ for aPC injections). Mice received atipamezole $(1 \mathrm{mg} / \mathrm{kg}$, s.c.; Antisedan, Pfizer) at the end of surgery to antagonize the medetomidine-induced effects and accelerate recovery from anesthesia. Mice were given carprofen ( $5 \mathrm{mg} / \mathrm{kg}$; Rimadyl, Pfizer) as an analgesic immediately before surgery, and carprofen-supplemented food (2 mg/ tablet) was provided for $4 \mathrm{~d}$ after surgery. Mice were singly housed after surgery and used 21-35 d after virus injection for GCaMP and iGLuSnFR and 21-71 d after injection for ChR2-EYFP.

Epifluorescence imaging. For in vivo epifluorescence imaging, mice were initially anesthetized with pentobarbital $(50-90 \mathrm{mg} / \mathrm{kg})$ followed by a booster if necessary and then maintained under isoflurane $(0.5-1 \%$ in $\mathrm{O}_{2}$ ) for data collection. Recordings began 2-3 h after the start of the preparation. Body temperature and heart rate were maintained at $37^{\circ} \mathrm{C}$ and $\sim 400$ beats per minute. We found that raphe stimulation was generally ineffective at higher isoflurane levels. Mice were doubletracheotomized and isoflurane was delivered directly to the tracheotomy tube, bypassing the nasal cavity. Animals were secured in a custom head holder or a stereotaxic device (Kopf Instrument) for further procedures and imaging, which followed previously established protocols (Wachowiak and Cohen, 2001; Bozza et al., 2004; Spors et al., 2006). Widefield epifluorescence signals were acquired either through thinned bone or after removal of the bone and dura overlying the dorsal OB. Recordings of epifluorescence signals were performed as described previously (Wachowiak et al., 2013) using a $4 \times, 0.28$ NA objective (Olympus) and digitized at $256 \times 256$ pixel resolution and $25 \mathrm{~Hz}$ frame rate using a CCD camera (NeuroCCD, RedShirt Imaging) and associated Neuroplex software. For in vivo pharmacology, methysergide maleate, cinanserin hydrochloride, or CGP35348 (all from Tocris Bioscience) were applied directly to the dorsal OB surface after removal of the dura

Extracellular recordings. For OB unit recordings, anesthesia and initial procedures were the same as described above. A small $(\sim 1 \times 1 \mathrm{~mm})$ craniotomy was performed over one $\mathrm{OB}$ and the dura removed. Extracellular recordings were obtained from $\mathrm{OB}$ units using a 16-channel electrode (NeuroNexus, A1x16-5mm50-413-A16) and an RZ5 digital acquisition system (TDT; Tucker Davis Technologies). Action potential 
waveforms with a signal-to-noise ratio of at least $4 \mathrm{SD}$ above baseline were detected and digitized on all 16 channels. Custom scripts in TDT were used to control odorant presentation and optical stimulation. Recordings from presumptive MT cells were isolated and selected as described previously (Carey and Wachowiak, 2011; Rothermel et al., 2014). Briefly, we isolated units off-line using user-supervised spike sorting (OpenSorter, TDT) with Bayesian or (in fewer cases) K-means cluster cutting algorithms. Waveforms were classified as a single neuron if they fell within discrete clusters in a space made up of principle components 1 and 2. Unit isolation was further confirmed by the distribution of interspike intervals. Units were included for further analysis if they were located in the vicinity of the mitral cell layer and showed clear activity in the absence of odorant. Electrode depth was monitored with a digital micromanipulator (Sutter Instruments, MP-225). Data were collected from multiple penetrations per animal. All recording sites were confined to the dorsal OB. Units were tested with up to 7 odorants. "Baseline" (ie, no stimulation) and stimulation trials were interleaved and repeated a minimum of three trials each, using an interstimulus interval of $70 \mathrm{~s}$. Recordings with at least five repeated trials of each were subject to unit-by-unit statistical analysis as described in the Text.

Odorant, electrical, and optical stimulation. Odorants, as specified in the Results, were presented as dilutions from saturated vapor (s.v.) in cleaned, humidified air using a custom olfactometer under computer control (Bozza et al., 2004; Verhagen et al., 2007). For concentrations $<0.4 \%$ s.v., pure odorant was diluted 1:10 in mineral oil and saturated vapor concentrations estimated based on this dilution factor. All odorants were obtained at 95-99\% purity from Sigma-Aldrich and stored under nitrogen. Odorants included propyl acetate, acetophenone, hexanal, isoamyl acetate, methyl benzoate, ethyl butyrate, 2-hexanone, methyl valerate, butyl acetate, isovaleric acid, and heptanal. Odorant stimulation was achieved using an artificial inhalation paradigm at $1 \mathrm{~Hz}$, with peak inhalation airflow of $\sim 300 \mathrm{ml} / \mathrm{min}$ and $150 \mathrm{~ms}$ inhalation duration as described previously (Wachowiak and Cohen, 2001; Spors et al., 2006). Inhalation timing and consistency was monitored with a pressure sensor. Inhalation of ambient air was achieved using the same inhalation protocol but without odorant presentation. Electrical stimulation targeting the DRN was performed using a concentric bipolar electrode (CBCPH-75, FHC) inserted through a small craniotomy at the coordinates (relative to bregma, in $\mathrm{mm}$ ) -4.1 anteroposterior, 0.5 mediolateral. The electrode was inserted at a $10^{\circ}$ angle from lateral toward medial to reach a dorsoventral depth of 2.1-2.8 mm. Electrode placement was confirmed with post hoc histology; however, stimulation of neurons in median, as well as dorsal, raphe is possible due to current spread and electrode size. Stimulus trains consisted of pulses of $200-500 \mu \mathrm{A}$ intensity (400 $\mu \mathrm{A}$ typical) and $100 \mu$ s duration except when specified otherwise. The standard delivery protocol of pulse trains was $4 \mathrm{~s}$ for $20 \mathrm{~Hz}(80$ pulses). For optical stimulation of serotonergic OB afferents, light was presented as a continuous $10 \mathrm{~s}$ pulse either alone or simultaneous with odorant presentation using a $470 \mathrm{~nm}$ LED and controller (LEDD1B, Thorlabs) and a $1 \mathrm{~mm}$ diameter glass fiber positioned close $(<2 \mathrm{~mm})$ to the $\mathrm{OB}$, as described previously (Rothermel et al., 2014). Total light output from the fiber was $1-10 \mathrm{~mW}$.

Epifluorescence data analysis. Basic processing and analysis of optical signals followed protocols previously described for epifluorescence imaging from OSNs (Wachowiak and Cohen, 2001; Verhagen et al., 2007; Wesson et al., 2008; Carey et al., 2009). Initial data processing included averaging across three to six repeated trials, then extracting fluorescence time courses from visually selected regions-of-interest (ROIs) for further time-series analysis. Peak odorant-evoked response amplitudes were measured from ROIs consisting of 9-12 pixels centered on well defined signal foci (Verhagen et al., 2007) and computed as the average signal in three to five frames centered around the peak of the inhalation-evoked response, minus the five-frame average immediately before the inhalation $(\Delta F)$, then divided by the resting fluorescence measured from the first five frames of the trial $(\Delta F / F)$. For display in the figures, odorant response maps were scaled from zero to $95 \%$ of the maximal $\Delta F$ for that map and pixel resolution doubled (to $512 \times 512$ ) using bilinear interpolation. Except when noted otherwise, effects of raphe stimulation were measured on a per-preparation basis ( $n=1$ observation per mouse) by spatial averaging of 5-12 ROIs distributed across the dorsal OB and averaging across three to six trials per condition (ie, absence and presence of raphe stimulation). Inhalation-linked response amplitudes were measured as the difference between the four frames at the peak of the inhalation response and the four frames preceding the response onset. Effects in the no odor condition were measured from the first inhalation immediately after the end of the stimulus train, compared with the last inhalation before the start of the train. Effects on odorant responses were measured by taking the ratio of the first inhalation response after the end of the stimulus train to that of the inhalation just preceding the start of the train [response ratio $(\mathrm{RR})=\Delta F_{\text {end }} / \Delta F_{\text {pre }}$ ] and comparing to the same measure using the corresponding inhalations in control trials; this ratio minimized confounds from trial-to-trial variations in absolute odorant response magnitudes. All measurements were made from a single OB per animal. Measurement of rise-times were made as described previously for rat optical signals (Wesson et al., 2008) by upsampling the signal traces and then fitting the optical signals to a double-sigmoid function and determining rise and decay times (defined as the time from $10 \%$ to $90 \%$ of maximal amplitude and decay from $90 \%$ to $10 \%$, respectively) from these fits. Analyses and statistical tests were performed with MATLAB, Neuroplex, or Origin. Summary data are reported as mean (or median) \pm SD unless otherwise stated. Medians were reported and nonparametric tests were performed when data did not meet a standard test for normality.

Electrophysiology data analysis. Responses to optical or odorant stimulation were analyzed differently depending on the experimental paradigm. Optical stimulation effects on spontaneous spike rate in the absence of artificial inhalation were measured by calculating spikes/s $(\mathrm{Hz})$ for the $9 \mathrm{~s}$ before or during stimulation. Effects on spiking during inhalation of room air were measured either as the average spike rate during the nine inhalations before or during optical stimulation and across multiple trials (minimum of three trials in each condition for all units), or by measuring the change in spike rate following inhalation $(\Delta$ spikes/s), taken from sniff-triggered averages of spiking from stimulation or prestimulation trials. Odorant-evoked responses with or without optical stimulation were measured as the difference in spike rate during odorant presentation, relative to the same number of inhalations just before odorant presentation ( $\Delta$ spikes/s). For statistical analysis, significance for changes in firing rate for baseline versus optical stimulation was tested as described in the Results.

Histology. Mice were killed with an overdose of sodium pentobarbital and perfused with PBS followed by $4 \%$ paraformaldehyde solution in PBS. Heads were postfixed overnight at $4^{\circ} \mathrm{C}$ and brains were extracted and stored in PBS until they were processed further. In most cases, tissue was vibratome-sectioned as described previously (Wachowiak et al., 2013) and expression evaluated from native fluorescence without immunohistochemical amplification. For verification of GCaMP expression in $\mathrm{TH}+$ neurons, immunohistochemical analysis was performed on $\mathrm{OB}$ sections from TH-Cre $\times$ Rosa-GCaMP3 mice as described by Wachowiak et al. (2013). Briefly, coronal sections (15-30 $\mu \mathrm{m})$ were stained with the primary antibody rabbit anti-TH (1:500; Bioscience Research Reagents $\mathrm{AB} 152$, Millipore) overnight at $4^{\circ} \mathrm{C}$. The primary antibody was detected with an AlexaFluor 543-conjugated goat anti-rabbit secondary antibody (1:1000;A-11010, Invitrogen). GCaMP3 expression was enhanced in cryosections of reporter animals with an FITC-conjugated GFP antibody (1:150; ab6662, Abcam). Sections were analyzed with an Olympus IX70 FV1000 or FV10i confocal laser scanning inverted microscope at $20 \times$ magnification and colocalization of TH and GCaMP was evaluated by manually counting cells from confocal stacks taken from three representative sections of the glomerular layer of the dorsal OB in each of the three animals.

\section{Results}

Raphe activation enhances sensory responses of inhibitory juxtaglomerular interneurons

To examine raphe-mediated modulation of defined OB circuit elements, we targeted expression of optical reporters to nonoverlapping $\mathrm{OB}$ neuron populations defined by the genetic 
markers: GAD65 (GAD2), TH, and PCdh21, which allows for selective expression in PG and granule cells, SA cells, and MT cells, respectively (Wachowiak et al., 2013). Inhalation- and odorant-evoked activity in each population, along with its modulation by electrical stimulation of raphe, was measured with epifluorescence imaging from the dorsal OB surface (Bozza et al., 2004; Wachowiak et al., 2013).

We first examined GAD65+ neurons by crossing RosaGCaMP3 or Rosa-GCaMP6f reporter mice (Ai38 or Ai95D) with GAD2-Cre mice. Both crosses showed GCaMP expression in granule cells and in PG cells of the glomerular layer (Fig. 1A), as described previously (Wachowiak et al., 2013; Fukunaga et al., 2014). Also as reported previously, odorants evoked strong fluorescence signals which were distributed broadly across the dorsal $\mathrm{OB}$, but whose distribution was dominated by discrete signal foci apparently corresponding to OB glomeruli (Fig. 1Bi). Although granule cell activity may contribute to the diffuse component of this signal, the depth of granule cell dendrites relative to those of PG cells, along with the reported sparse activity in granule cells under anesthesia (Kato et al., 2012; Cazakoff et al., 2014) suggest that the majority of the GAD2 + GCaMP signal reflects PG cell activation. Temporally, odorant-evoked responses were strongly modulated by inhalation and showed odorant- and glomerulusspecific dynamics of onset latencies matching those reported previously for OSNs and other OB cell types (Fig. 1Bii; Wachowiak et al., 2013). In the majority of preparations (12 of 17 GCaMP3expressing mice; 4 of 4 GCaMP6f-expressing mice), inhalation of ambient air (ie, with no odorant) evoked smaller-amplitude fluorescence signals detectable above baseline in select dorsal foci (Fig. $1 B, D$ ), presumably reflecting responses to weak activation of OSNs by inhalation alone (Grosmaitre et al., 2007; Carey et al., 2009).

Raphe neurons were stimulated with a train of pulses at $20 \mathrm{~Hz}$ (4 s duration), approximating the maximal episodic firing rates of DRN neurons during odor-guided behavioral tasks (Ranade and Mainen, 2009). Stimulating raphe in the absence of artificial inhalation and, thus, in the absence of coherent sensory input, evoked a fluorescence increase beginning immediately after stimulation onset and decaying gradually back to baseline after stimulation ceased (Fig. 1C). This increase was distributed heterogeneously across the dorsal $\mathrm{OB}$ and reached peak magnitudes of $\sim 20 \%$ (20.0 $\pm 3.3 \% ; n=3$ GCaMP6f-expressing mice) of the peak odorant-evoked signals in the same regions.

Raphe stimulation during $1 \mathrm{~Hz}$ inhalations of ambient air led to a strong enhancement of inhalation-linked response transients across the dorsal OB (Fig. 1D). Inhalation-linked fluorescence increases were also distributed heterogeneously across the dorsal OB. Average maximal inhalation-linked responses, measured as $\Delta F / F$ from the trough to the peak of the fluorescence signal following an inhalation pulse (Fig. 1Dii), increased from $0.78 \pm$ $2.5 \%$ to $4.3 \pm 4.7 \% \Delta F / F$ (median $\pm \mathrm{SD}, n=11$ mice; $p<0.001$, paired Wilcoxon signed ranks test). Averaging response traces from eight mice expressing GCaMP3 $(n=6)$ or GCaMP6f $(n=2$; 6-10 ROIs per mouse) showed that raphe modulation began by the time of the first inhalation after the start of stimulation, with responses continuing to increase throughout the stimulus train (Fig. 1D). Enhanced responses recovered gradually, with a mean residual amplitude of $45.3 \pm 11.1 \%$ of the maximal inhalation response $6 \mathrm{~s}$ after the end of raphe stimulation (measured from $n=20$ ROIs; 4 mice expressing GCaMP3), suggesting that the modulatory effects of raphe activation outlast changes in raphe activity itself.
The duration and magnitude of raphe-mediated enhancement of GAD2 + neuron responses was dependent on the duration of raphe stimulation, with shorter stimulus trains eliciting a smaller increase in inhalation-linked response amplitudes as well as a shorter-duration increase in response after the end of the stimulus train (Fig. 1E). In two mice we compared the effects of our standard 80 pulse, $20 \mathrm{~Hz}$ stimulation protocol with that of the same 3 pulse, $10 \mathrm{~Hz}$ (1 ms pulse duration) protocol recently shown to modulate MT responses in vivo (Kapoor et al., 2016). We found that the 3 pulse protocol elicited reliable increases in inhalation responses in only one of the two mice; these increases were smaller and were significantly elevated above prestimulation levels for only two inhalation cycles after the stimulus train (Fig. 1E).

Next, we tested the effect of raphe stimulation on odorant responses in GAD2 + neurons by delivering the stimulus train during prolonged odorant presentation at suprathreshold concentration $(0.1-1 \%$ s.v.; Fig. $1 F)$. In this paradigm, inhalationlinked odorant responses have typically reached a stable repeated pattern after the initial large-amplitude response to odorant onset by the time raphe stimulation begins. To assess stimulation effects independent of adaptation over the period of the stimulus train and independent of trial-to-trial variations in absolute response amplitude, we compared the RR (see Materials and Methods) of inhalation-linked responses before and after the raphe stimulation period with the same measure taken from control (non-stimulation) odorant trials (Fig. $1 F$ ). Raphe stimulation increased odorant-evoked responses using this measure (Fig. $1 F, G)$, with a significant increase in $\mathrm{RR}$ measured across odorant-responsive ROIs (control RR $=0.79 \pm 0.11$, stim $\mathrm{RR}=$ $0.93 \pm 0.18$, mean $\pm \mathrm{SD} ; p<0.01$, paired $t$ test, $n=10$ mice, 8-10 ROIs averaged per mouse).

Overall, these results suggest that raphe stimulation dramatically increases PG cell responses to sensory input, including strong sensory input driven by odorant stimulation, as well as weaker sensory input driven by inhalation of ambient air. Raphe stimulation also rapidly increases tonic excitation of PG cells and/or granule cells, as predicted from recent reports that serotonin increases spontaneous excitatory drive to PG cells and depolarizes granule cells in vitro (Schmidt and Strowbridge, 2014; Brill et al., 2016).

We next examined effects of raphe stimulation on SA cells, a population of GABAergic/dopaminergic juxtaglomerular neurons distinguished by their expression of the GAD67 isoform and of TH (Kosaka and Kosaka, 2008; Kiyokage et al., 2010). In contrast to PG cells, SA cell neurites branch widely in the glomerular layer and can mediate interglomerular inhibition (Liu et al., 2013; Banerjee et al., 2015). In TH-Cre $\times$ Rosa-GCaMP3 (5 mice) or GCaMP6f crosses (4 mice), GCaMP was expressed primarily in glomerular layer neurons and in sparsely distributed EPL neurons, as described previously (Fig. 2A; Wachowiak et al., 2013). Within the glomerular layer, $93 \pm 2.9 \%$ of TH-positive cells ( 545 cells of 3 animals counted) expressed GCaMP3. As with the GAD2 + neuron population, sensory-evoked GCaMP signals imaged from $\mathrm{TH}+$ neurons were strongest in foci presumably reflecting OB glomeruli (Fig. 2Bi) and were temporally coupled to inhalation, with inhalation-linked transients apparent during inhalation of both air and odorants (Fig. 2Bii).

In contrast to GAD2 + neurons, however, raphe stimulation did not cause a change in baseline fluorescence in $\mathrm{TH}+$ neurons when delivered in the absence of inhalation (Fig. 2Ci; mean $\Delta F$ / $F=0.49 \pm 0.67 ; p=0.18$, one-sample $t$ test, $n=5$ mice). Raphe stimulation strongly enhanced the responses of $\mathrm{TH}+$ neurons to inhalation of ambient air, similar to its effect on GAD2 + responses (Fig. 2Cii,Ciii). Maximal inhalation-evoked responses 

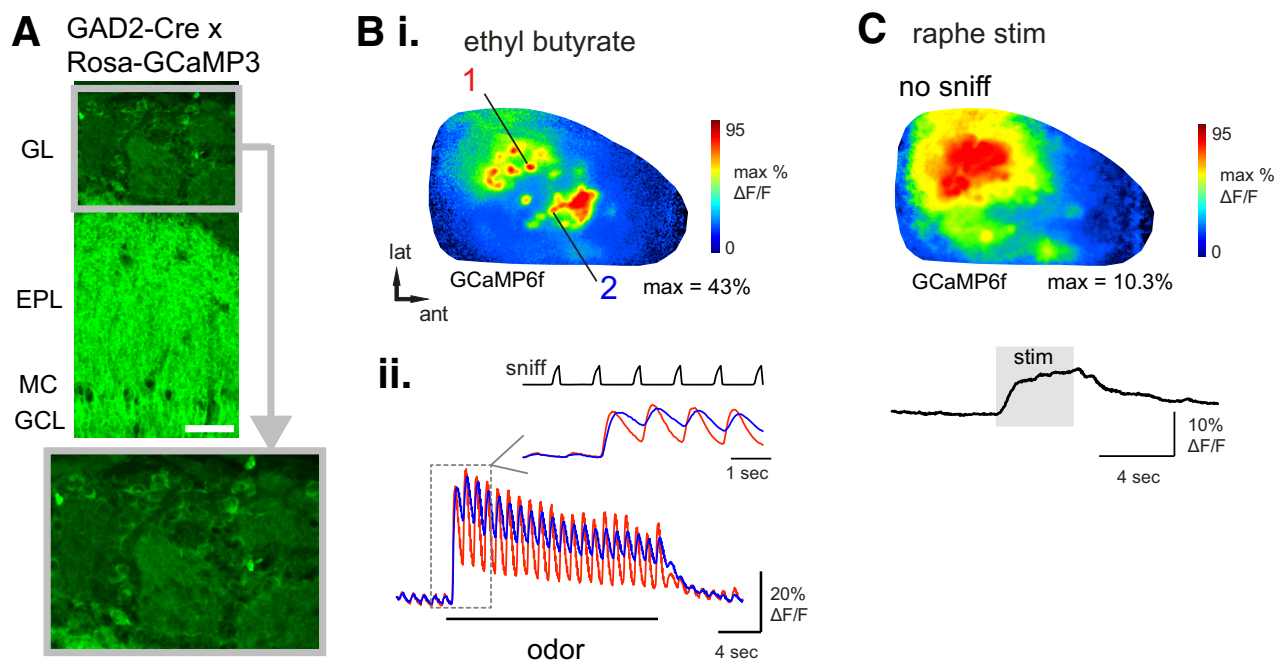

ii.

D i. raphe stim
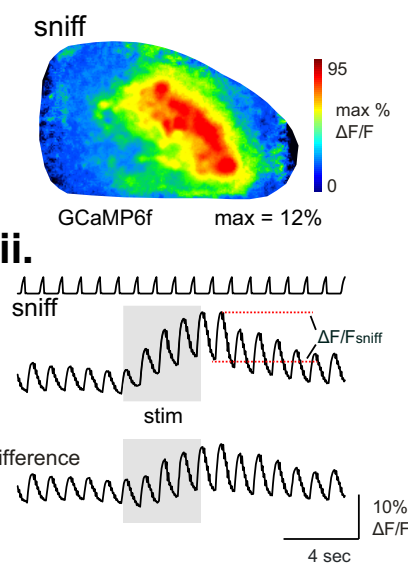

iii.

F odor

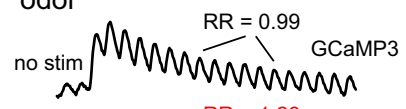

$\mathrm{RR}=1.28$

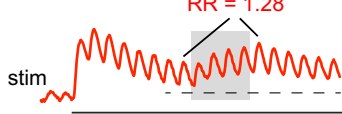

odor (ethyl butyrate)
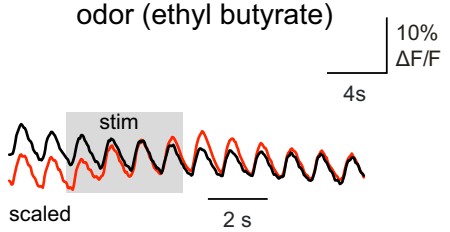

G

ii.

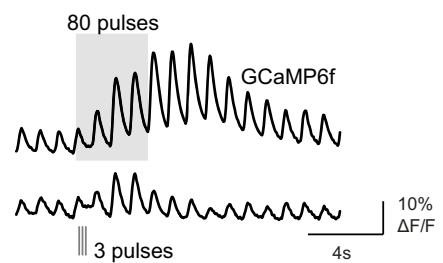

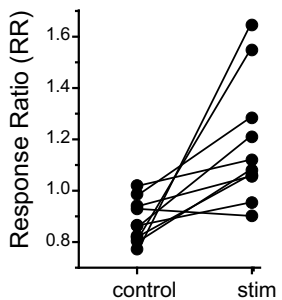

Figure 1. Electrical stimulation of raphe enhances sensory responses in GAD65-positive OB neurons. A, Overview of GCaMP3 expression in the OB of a GAD2-Cre:Rosa-GCaMP3 cross. Bottom, Magnified view of glomerular layer, with individual PG somata visible around the periphery of the glomerulus. Scale bar, $50 \mu \mathrm{m}$. GL, Glomerular layer; EPL, external plexiform layer; MC, mitral cell layer; GCL, granule cell layer. B, Odorant-evoked GCaMP signals imaged from the dorsal OB of a GAD2-Cre:Rosa-GCaMP6f mouse. Bi, Response map showing change in fluorescence evoked by ethyl butyrate (0.1\%, S.v.). Bii, Traces showing time course of GCaMP signal in two ROls in the caudal-lateral (1) and rostral-medial (2) OB, with distinct inhalation-linked time courses in each ROI. Inset, Expansion of boxed region illustrating temporal differences. "Sniff" trace in inset shows timing of artificial inhalation. C, GAD2+ GCaMP6f signal evoked by raphe stimulation $(20 \mathrm{~Hz}, 80$ pulses) in the absence of inhalation-driven sensory input. Same preparation as in $\boldsymbol{B}$. Top, Response map showing fluorescence change after raphe stimulus train. Note widespread increase with multiple foci of high-magnitude increases. Trace shows time course of GCaMP6f signal averaged across $10 \mathrm{RO}$ Is from the same preparation. $\boldsymbol{D}, \mathrm{GAD2}+\mathrm{GCaMP} 6 \mathrm{f}$ signal during artificial inhalation of ambient air and raphe stimulation. Same preparation as in $\boldsymbol{B}$. Di, Response map showing inhalation-linked fluorescence change during raphe stimulation, defined as $\Delta F / F_{\text {sniff }}$ in Dii. Inhalation-evoked responses are widespread across the dorsal $0 B$ but include distinct foci of peak enhancement. Dii, Time course of GCaMP6f signal (same ROIs as in C) during inhalation of ambient air (sniff), before and after (difference) subtracting the trace of raphe stimulation without inhalation, showing persistent increases in inhalation response amplitudes. Diii, Time course of mean GCaMP signal elicited by raphe stimulation, normalized and averaged across eight mice. Shaded area indicates SD across mice. Across all mice, stimulation strongly enhances inhalation responses, which persist for at least $8 \mathrm{~s}$ after stimulation ceases. $\boldsymbol{E}$, Increasing raphe stimulus train duration increases both the magnitude and duration of the enhanced response to air inhalation. Ei, GCaMP3 traces taken from a single ROI during stimulus trains from 20 pulses to 80 pulses (all at $20 \mathrm{~Hz}$ ). Current intensity, $400 \mu \mathrm{A}$. Eii, GCaMP6f traces from a different preparation comparing responses during the standard 80 pulse train (top) with responses to a train of 3 pulses of $1 \mathrm{~ms}$ duration, delivered at $10 \mathrm{~Hz}$. Current intensity, $250 \mu \mathrm{A}$. $\boldsymbol{F}$, Raphe stimulation increases inhalation-linked response magnitudes during odorant inhalation. Traces show mean signal averaged across 10 odorant-responsive ROIs from the same preparation, without (black) and with (red) raphe stimulation delivered during a prolonged odorant presentation (ethyl butyrate, $0.2 \%$, s.v.). RR is defined as the ratio of the inhalation responses before and after stimulation within the same trial. See Results for details. Bottom traces show an excerpt from each trial (indicated by horizontal dashed line) with the vertical scales normalized to the same inhalation response amplitude for the inhalation just before the raphe stimulus train. G, Effect of raphe stimulation on odorant-evoked RRs, measured from signals averaged across 8-10 responsive ROls in each of 10 preparations, with and without raphe stimulation. Each pair of points represents one mouse. 


\section{A TH-Cre $x$ Rosa-GCaMP3}

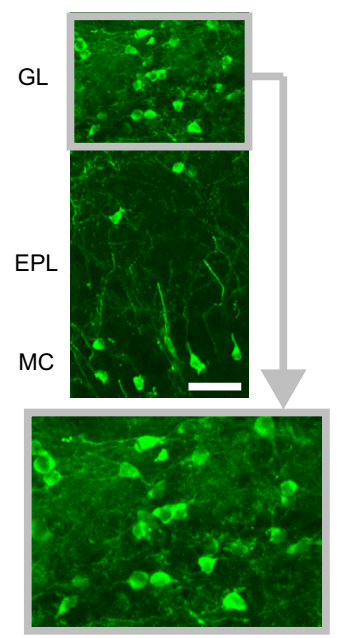

D i. sniff

annmannmar
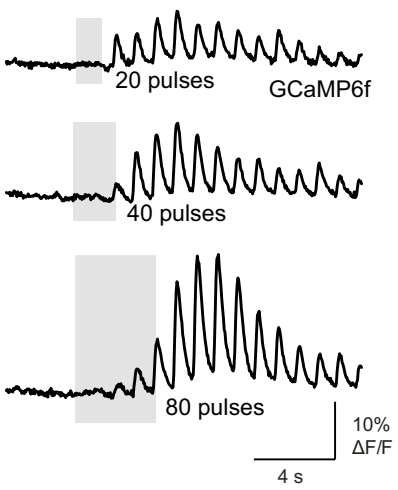

ii.

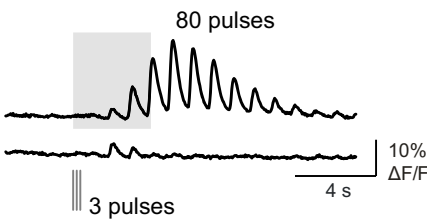

B i.

ethyl butyrate (1\% s.v.)

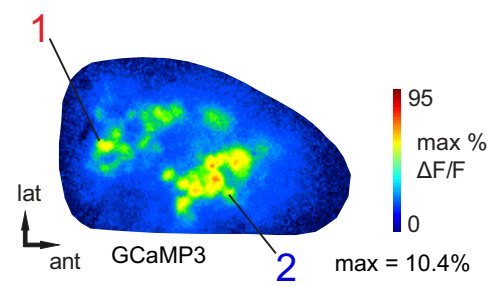

ii.

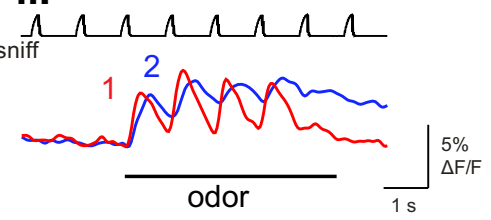

E odor

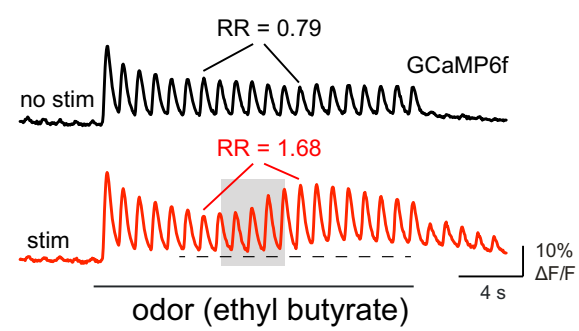

munhonhonma

$\mathbf{F}$

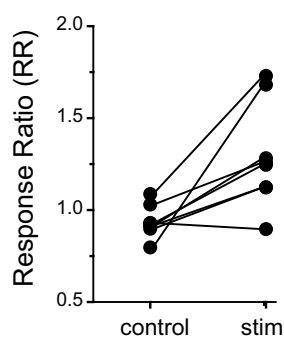

C i. raphe stim

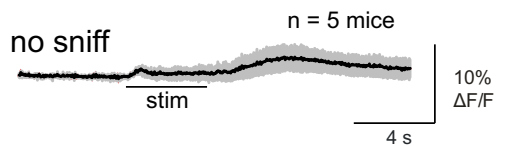

ii. sniff
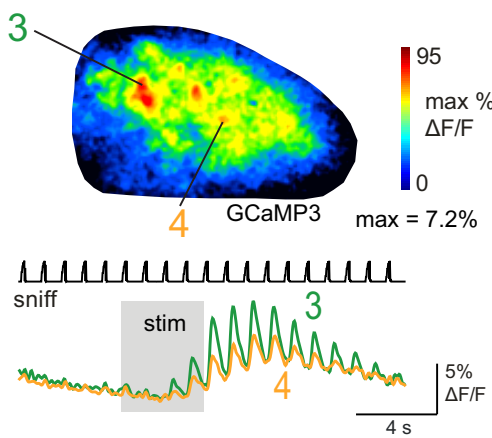

iii.

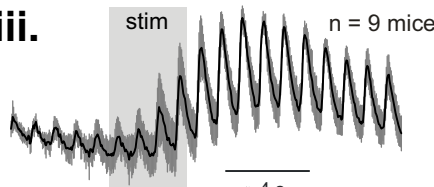

Figure 2. Electrical stimulation of raphe enhances sensory responses in TH-positive juxtaglomerular neurons. A, Overview of GCaMP3 expression in the OB of a TH-Cre:Rosa-GCaMP3 cross. Lower image shows magnified view of glomerular layer, with individual SA somata visible. Scale bar, $50 \mu \mathrm{m}$. B, Odorant-evoked responses imaged from a TH-Cre:Rosa-GCaMP3 mouse. $\boldsymbol{B} \boldsymbol{i}$, Response map showing change in fluorescence evoked by ethyl butyrate (1\%, S.v.). Bii, Time course of GCaMP3 signal in two ROls located in the caudal-lateral (1) and anteromedial (2) $O B$, with distinct inhalation-linked time courses similar to those seen for GAD2 + signals. C, Raphe modulation of TH + GCaMP signal during artificial inhalation of ambient air and raphe stimulation ( $20 \mathrm{~Hz}, 80$ pulses). Ci, Mean and SD of GCaMP signal evoked by raphe stimulation in the absence of inhalation ("no sniff"), averaged from air-responsive ROls in five mice, showing no significant change in fluorescence during raphe stimulation and a slight increase after the end of the train attributable to hemodynamic effects. Cii, Response map showing GCaMP3 fluorescence change after raphe stimulation (same preparation as in $\boldsymbol{B}$, with widespread increases and peak increases in distinct foci. Cii, Traces taken from two ROls showing time course of stimulation effect. Ciii, Time course of mean and SD of GCaMP signal elicited by raphe stimulation, averaged across nine mice. As with the GAD2 + signal, raphe stimulation effects on the TH + GCaMP signal persist for at least $8 \mathrm{~s}$ after stimulation ceases. $\boldsymbol{D}$, Effect of raphe stimulus train duration on $\mathrm{TH}+$ responses to air inhalation. Traces show GCaMP6f signal averaged from $10 \mathrm{ROIs}$ in one mouse. Di, Responses to stimulus trains $(20 \mathrm{~Hz})$ of increasing duration elicit larger and longer-lasting enhancement of inhalation responses. Current intensity, $400 \mu \mathrm{A}$. Dii, Different preparation showing comparison of effects of an 80 pulse, $20 \mathrm{~Hz}$ train $(0.1 \mathrm{~ms}$ pulse duration) and a 3 pulse, $10 \mathrm{~Hz}$ train (1 ms pulse duration) measured from the same ROls. (urrent intensity, $250 \mu \mathrm{A}$. $\boldsymbol{E}$, Traces showing raphe-stimulated increase in inhalation-linked responses in $\mathrm{TH}+$ neurons during odorant inhalation. Traces show mean GCaMP6f signal averaged across 10 odorant-responsive ROIs from the same preparation, delivered during presentation of odorant (ethyl butyrate, $0.1 \%$, s.v.), as in Figure 1. Bottom traces show an excerpt from each trial (indicated by horizontal dashed line) with the vertical scales normalized to the same inhalation response amplitude for the inhalation just before the raphe stimulus train. $\boldsymbol{F}$, Effect of raphe stimulation on odorant-evoked RRs, measured and plotted for each of eight $\mathrm{TH}+$ preparations as in Figure 1. 
A

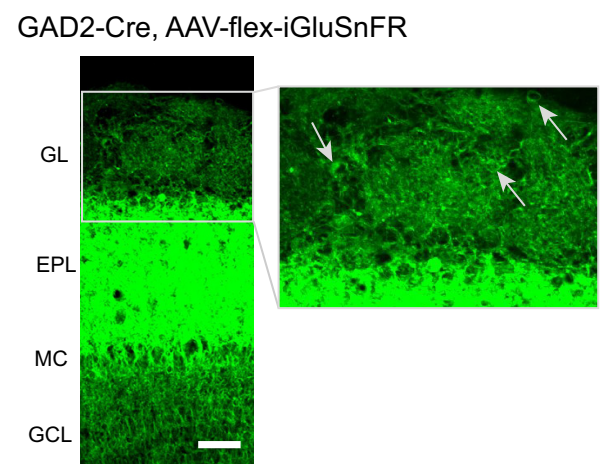

B i.

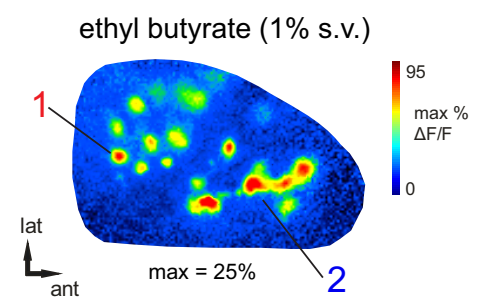

C

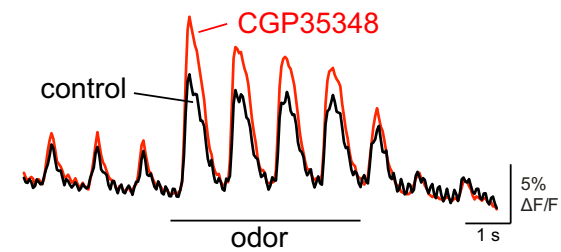

ii.
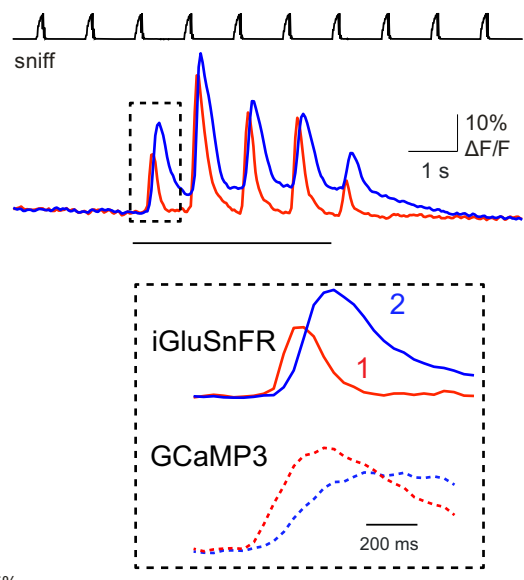

D

TH-Cre, AAV-flex-iGluSnFR
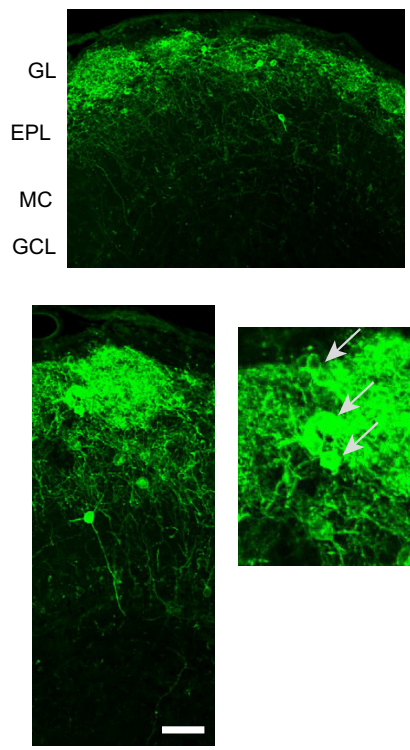

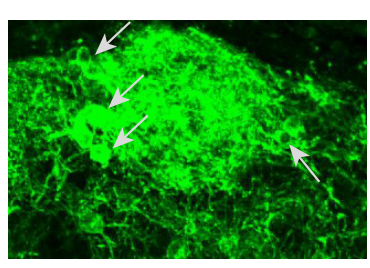

E i.

ethyl butyrate $(0.2 \%$ S.v. $)$

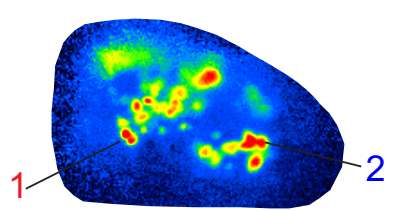

phenetole

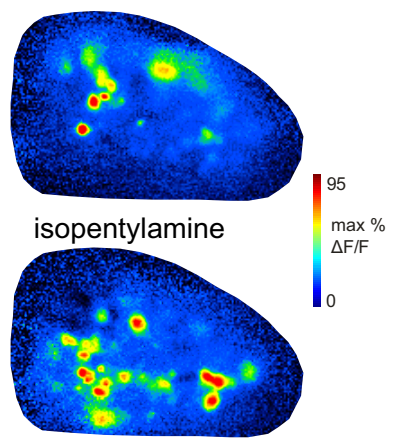

ii.
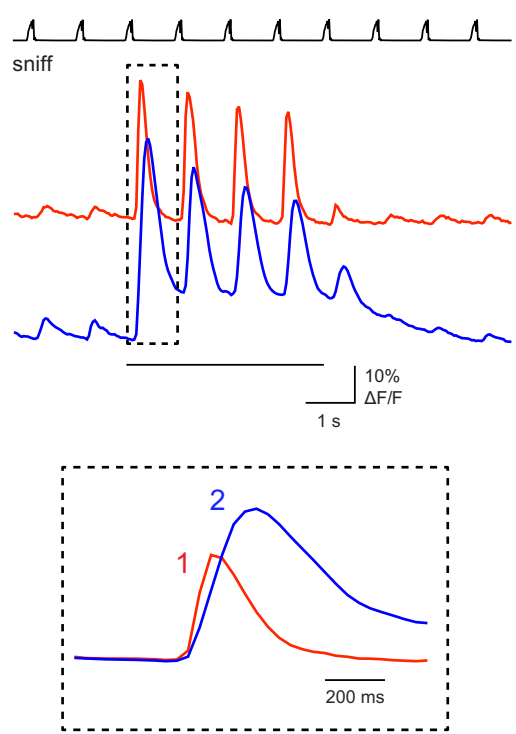

Figure 3. Imaging glutamatergic input to juxtaglomerular interneurons with iGluSnFR. $A$, Expression of $\mathrm{GGluSnFR} \mathrm{in} \mathrm{GAD2}+\mathrm{OB}$ neurons after injection of $A A V$-flex-iGluSnFR into the $0 B$ of a GAD2-Cre mouse, with similar expression patterns to GAD2-Cre:Rosa-GCaMP3 crosses. Right panel shows magnified view of glomerular layer. Arrows indicate presumed PG cell somata. Scale bar, $50 \mu \mathrm{m} . \boldsymbol{B}$, iGluSnFR response map (Bi) and traces (Bii) showing time course of iGluSnFR signal taken from a caudal-lateral (1) and anteromedial (2) Rol. Inset, Expansion of iGluSnFR response to first inhalation of odorant for each ROI, with GCaMP3 signals imaged from ROls taken from similar dorsal locations (same data as from Fig. 1B) shown for comparison. Note faster onset and decay kinetics for iGluSnFR compared with GCaMP3 signals, but with a similar temporal shift between anteromedial and caudal-lateral ROls. C, Odorant-evoked iGluSnFR signal (average of 10 ROIs) in control conditions and after topical application of the $\mathrm{GABA}_{B}$ receptor antagonist $\mathrm{CGP3} 3348(1 \mathrm{mM})$, showing an increase in inhalation-linked glutamate release onto GAD2 + neurons. $D$, Expression of iGluSnFR in TH $+O B$ neurons after injection of AAV-flex-iGluSnFR into the OB of a TH-Cre mouse, with similar expression patterns to TH-Cre:Rosa-GCaMP3 crosses. Bottom, Magnified view of glomerular layer. Arrows indicate presumed SA cell somata. Scale bar, $50 \mu \mathrm{m}$. $\boldsymbol{E}$, iGluSnFR response maps (E) and traces (Eii) taken from a caudal-lateral (1) and anteromedial (2) ROI. Maps show clear glomerular foci with distinct spatial response patterns for each odorant. Inset, Expansion of iGluSnFR response to first inhalation of odorant for each ROI. This example also includes clear responses to inhalation preceding odorant presentation.

increased from $0.62 \pm 1.6$ to $4.0 \pm 5.2 \% \Delta F / F[$ median $\pm \mathrm{SD}, n=$ 9 mice (5 GCaMP3, 4 GCaMP6f]; $p=0.004$, paired Wilcoxon signed ranks test). Raphe-mediated increases in responsiveness were widely but heterogeneously distributed across the OB (Fig. 2Cii). The time course of averaged raphe-mediated enhancement of $\mathrm{TH}+$ responses $(n=9$ mice) was qualitatively similar to that seen for GAD2 + neurons, with inhalation-linked responses increasing in magnitude over the course of the $4 \mathrm{~s}$ stimulus train and returning gradually to prestimulation levels (mean residual amplitude of $47.3 \pm 11 \%$ of the maximal amplitude $6 \mathrm{~s}$ after the end of the stimulus; $n=20$ ROIs measured from 4 mice; Fig. 2Ciii). Increasing the duration of raphe stimulation increased both the magnitude and duration of the response enhancement (Fig. 2D). The short, 3 pulse, $10 \mathrm{~Hz}$ stimulus train used by Kapoor et al. (2016) (tested in 3 mice) elicited reliable increases in only one of three mice tested, lasting for four inhalations after stimulation (Fig. 2D). Also as with GAD2 + neurons, raphe stimulation enhanced odorantevoked responses, with a significant increase in odorant RR for the 
A GAD2-Cre, AAV-flex-iGluSnFR

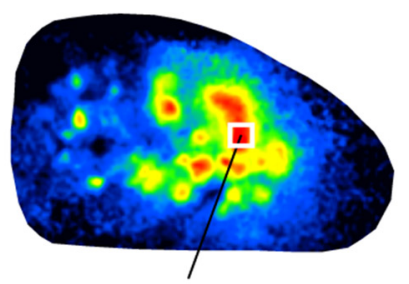

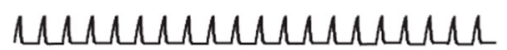
sniff
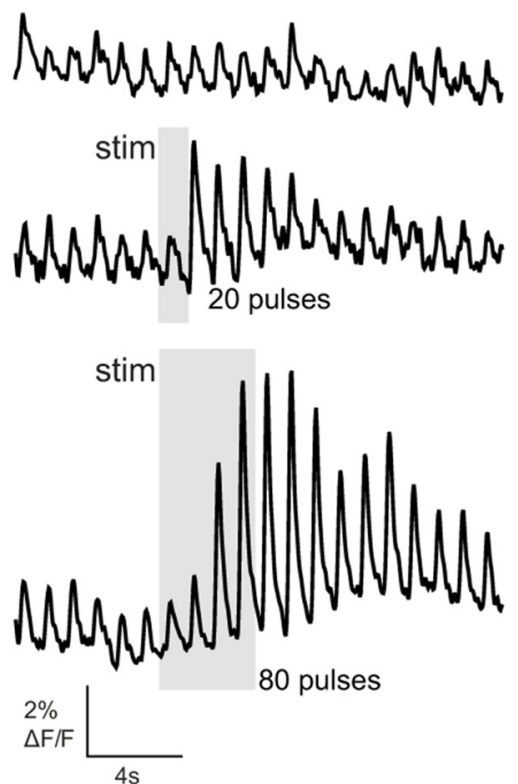

B
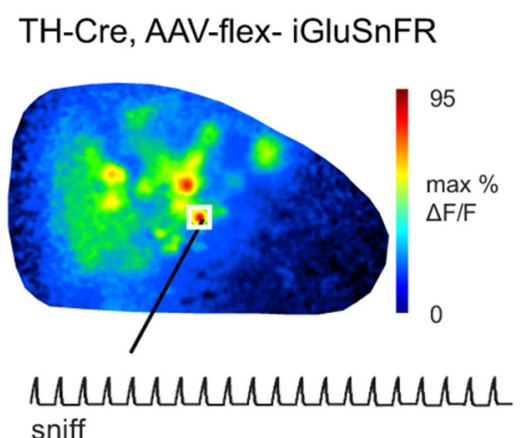
sniff
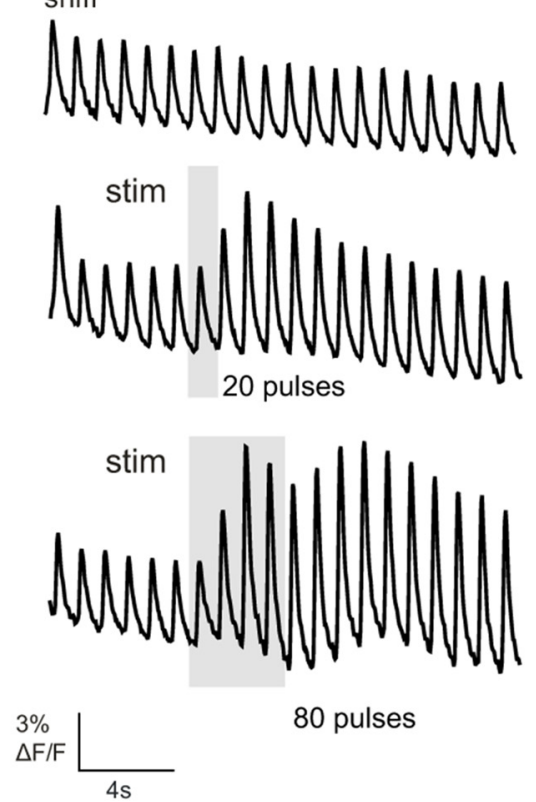

Figure 4. Electrical stimulation of raphe enhances inhalation-driven glutamatergic input to juxtaglomerular interneurons. $\boldsymbol{A}$, Raphe stimulation elicits an increase in the magnitude of inhalation-linked iGluSnFR transients imaged from GAD2 + neurons during inhalation of ambient air. Traces show time course of iGluSnFR signal with no stimulation (top trace), a 20 pulse stimulus train (middle trace) and an 80 pulse train (bottom trace). Response map at top shows map of fluorescence increase at the end of the 80 pulse train. White square indicates ROI from which traces are taken. $\boldsymbol{B}$, Raphe stimulation causes a similar increase in iGluSnFR signals imaged from $\mathrm{TH}+$ neurons, with increasing effect size and duration with a longer ( 80 pulse) stimulus train.

period of raphe stimulation ( $p=0.01$, paired $t$ test; $n=7$ mice, $8-12$ ROIs per mouse; Fig. $2 E, F)$. In summary, these data suggest that raphe activation differentially affects baseline excitation but similarly modulates sensory-evoked responses of PG and SA cells, the two major inhibitory cell types of the glomerulus, transiently and dramatically increasing their responses to inhalation-driven sensory input.

\section{Raphe modulation involves increased sensory-driven glutamatergic input to interneurons}

Raphe-mediated enhancement of PG and SA cell responses could be due to direct, serotonergic modulation of excitability or to modulation presynaptic to these neurons. To investigate this we used an optical reporter of glutamatergic signaling, iGluSnFR (Marvin et al., 2013), expressed selectively in GAD2+ or TH+ interneurons, to monitor excitatory inputs to each cell type. Known sources of glutamatergic inputs to PG and SA cells include feedforward excitation from OSNs and ET cells, as well as dendrodendritic excitation from MT cells (Isaacson, 1999; Najac et al., 2015). For these experiments, iGluSnFR was expressed using a Cre-dependent viral vector injected into the dorsal OB of the appropriate mouse line (see Materials and Methods). iGluSnFR expression patterns in the OBs of GAD2- and TH-Cre mice were similar to those of previously characterized virally driven GCaMP3 expression (Wachowiak et al., 2013; Fig. $3 A, D$ ).

We first characterized odorant- and inhalation-driven iGluSnFR signals in the absence of raphe stimulation. With either cell type, odorants evoked strong iGluSnFR fluorescence increases whose spatial and temporal organization was qualitatively similar to that observed with GCaMP imaging. Odorant response maps were dominated by discrete glomerular signal foci distributed in odorant-specific domains matching those observed with imaging from OSNs and GCaMP3 signals (Bozza et al., 2004; Wachowiak et al., 2013; Fig. $3 B, E$ ). Temporally, iGluSnFR responses consisted primarily of inhalation-driven transients with rise and decay times faster than those observed for GCaMP3 signals imaged from GAD + and $\mathrm{TH}+$ neurons. For example, transients in caudal-lateral regions, which show the most rapid rise and decay times evoked by inhalation of ethyl butyrate (Wachowiak et al., 2013), had rise and decay times (defined in Materials and Methods) for GCaMP3 of $t_{(10,90)}=280 \pm 66 \mathrm{~ms}$ and $t_{(90,10)}=1372 \pm 248 \mathrm{~ms}$, respectively, compared with iGluSnFR rise and decay times of $96 \pm 22 \mathrm{~ms}$ and $332 \pm 54 \mathrm{~ms}$ (median $\pm \mathrm{SD} ; n=3$ animals, 5 ROIs per animal for both groups; Fig. $3 B, E$ ). Inhalation of ambient air evoked smallamplitude fluorescence transients (1-4\% $\Delta F / F)$, detectable in most preparations, while odorants elicited larger transients of $19.1 \pm 10.1 \% \Delta F / F(\max 44.5 \% \Delta F / F)$ and $25 \pm 15.6 \% \Delta F / F(\max 72.6 \% \Delta F / F)$ for GAD2 $+(n=23$ ROIs from 4 animals $)$ and $\mathrm{TH}+(n=63$ ROIs from 10 animals $)$ animals, respectively. These stronger odorant responses typically also included a tonic iGluSnFR component that returned more slowly to baseline after odorant presentation ceased. Inhalation-linked iGLuSnFR transients showed the same temporal difference of anterior medial versus posterior lateral glomeruli that was described for GCaMP3 signals previously (Wachowiak et al., 2013; Fig. 3 B,E, magnified traces). Finally, pharmacologically increasing the magnitude of sensory-evoked glutamate release by blocking presynaptic inhibition of OSNs using the $\mathrm{GABA}_{\mathrm{B}}$ antagonist CGP35348 (1 mM; McGann et al., 2005; Wachowiak et al., 2005) led to an increase in the magnitude of inhalation-linked iGluSnFR transients (Fig. $3 C)$. Overall, these response characteristics are consistent with iGluSnFR reporting feedforward, intraglomerular glutamate signaling with high temporal precision and dynamic range.

In both GAD2-Cre and TH-Cre mice, raphe stimulation enhanced the iGluSnFR response to inhalation of ambient air (Fig. $4 A, B)$. GAD2 + PG cell responses to inhalation increased from $1.3 \pm 0.3$ to $3.3 \pm 1.1 \% \Delta F / F(n=3$ mice $)$, whereas $\mathrm{TH}+\mathrm{SA}$ cell responses increased from $2.3 \pm 2.1$ to $6.1 \pm 2.5 \% \Delta F / F$ after raphe stimulation ( $n=5$ mice, mean $\pm \mathrm{SD}, p=0.01$, paired $t$ test). The time course of the raphe-mediated enhancement was similar to that of its effect on the GCaMP3 signal in PG and SA 
A

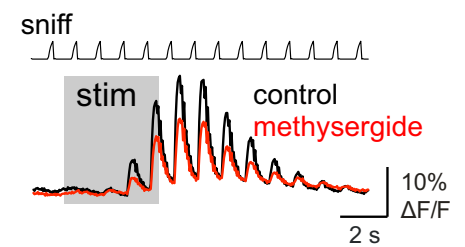

sniff

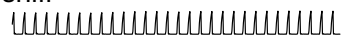

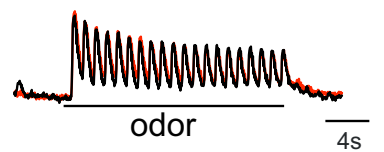

B

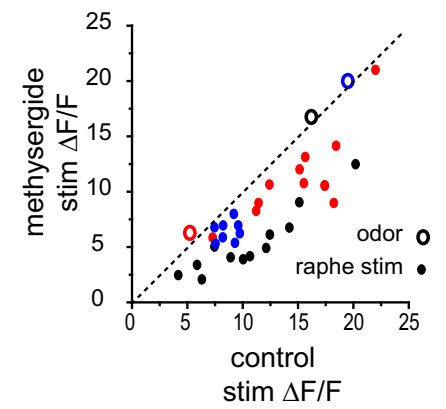

C

sniff

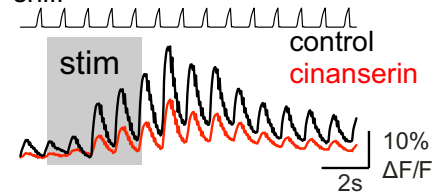

sniff

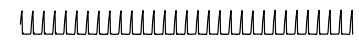

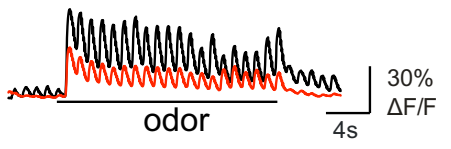

Figure 5. 5-HT receptor antagonists partially block raphe stimulation effects on sensory responses. A, Top, GCaMP6f signals imaged from TH + neurons showing raphe stimulation enhancement of responses to air inhalation in control conditions and after application of the 5 -HTR antagonist methysergide ( $200 \mu \mathrm{M})$. Bottom, Signals from the same ROls showing that odorant-evoked signals are unaffected by methysergide. $\boldsymbol{B}$, Scatter plot of inhalation-linked responses measured from individual ROls from three preparations ( 2 TH +; black, red points, $1 \mathrm{GAD2}+$; blue points), showing response to air inhalation (measured from the first inhalation after the end of the stimulus train) in control versus after methysergide conditions. All ROIs show suppressed response amplitudes. Large circles show mean odorant-evoked response amplitudes, averaged across the same ROIs in each preparation, showing no effect on odorant responses. C, Example of GCaMP6f signals imaged from $\mathrm{GAD2}+$ neurons showing effects of the $5-\mathrm{HT}_{2} \mathrm{R}$-selective antagonist cinanserin $(200 \mu \mathrm{M})$ on responses to air and odorant inhalation. Cinanserin reduces the effect of raphe stimulation (top traces), but also suppresses responses to air and odorant inhalation in the absence of stimulation (bottom traces, same ROls).

cell populations (Fig. 4A,B). Raphe-mediated enhancement of PG and SA iGluSnFR responses also showed a similar dependence on the duration of raphe stimulation (Fig. $4 A, B$ ). These results suggest that the raphe-mediated enhancement of $\mathrm{PG}$ and SA cell responsiveness, as imaged with GCaMPs, is substantially mediated by an increase in sensory-driven glutamatergic inputs to these neurons, either from superficial or external tufted cells, mitral cells, or directly from OSNs.

\section{Raphe modulation is only partially mediated by serotonergic signaling}

A recent study of raphe modulation of OB MT cells suggested that modulation of MT cell excitability by brief raphe stimulation is mediated largely by glutamate release from serotonergic raphe afferents (Kapoor et al., 2016). In addition, raphe activation could lead to modulation of $\mathrm{OB}$ neuron responses via indirect pathways, for example, by modulating other sources of centrifugal input to the $\mathrm{OB}$, such as piriform cortex (Boyd et al., 2015; Otazu et al., 2015; Lottem et al., 2016). We tested whether the enhanced sensory responses of PG and SA cells after raphe stimulation were dependent on serotonergic signaling in the OB by applying 5-HT receptor (5HTR) antagonists to the dorsal OB surface while imaging GCaMP6f signals in $\mathrm{GAD} 2+$ or $\mathrm{TH}+$ neurons.

$5 \mathrm{HTR}$ antagonists partially reduced the effects of raphe stimulation. Methysergide $(200 \mu \mathrm{M})$, a blocker of $5-\mathrm{HT}_{1}$ and $5-\mathrm{HT}_{2}$ receptor subtypes, reduced the magnitude and duration of enhanced GCaMP6f responses to inhalation of ambient air in $\mathrm{TH}+$ neurons ( $n=2$ mice, $)$ and GAD2 + neurons ( $n=1$ mouse), with little impact on inhalation- or odorant-evoked responses themselves (ie, in the absence of stimulation; Fig. $5 A, B$ ). Inhalationlinked response amplitudes after the stimulus train were significantly reduced in each mouse, by $50 \pm 11 \%\left(p=3 \times 10^{-6}\right.$, paired $t$ test $)$ and $23 \pm 18 \%\left(p=7 \times 10^{-4}\right)$ for the two $\mathrm{TH}+$ mice $(n=8$ ROIs each $)$ and $24.7 \pm 11 \%\left(p=9 \times 10^{-4}, n=8\right.$ ROIs) for the GAD2 + mouse, whereas mean odorant-evoked response amplitudes across the same ROIs remained unchanged ( $100.4 \pm 4.4 \%$ of pre-drug response, $n=32$ ROIs; Fig. $5 B$ ). Cinanserin $(200 \mu \mathrm{M})$, a more selective $5-\mathrm{HT}_{2}$ receptor antagonist, also reduced raphe stimulation effects, but at the same time strongly reduced sensory responses (to air or odorant inhalation) even in the absence of raphe stimulation (Fig. 5C), confounding interpretation of its effects on raphe modulation. Nonetheless, raphe-mediated enhancement of inhalation-driven responses persisted in the presence of cinanserin (Fig. 5C). These results suggest that the enhanced responsiveness of PG and SA cells to sensory input after brief raphe activation is partially mediated by local serotonergic signaling in the OB and likely partially mediated by other neurotransmitter pathways, such as direct glutamatergic excitation (Kapoor et al., 2016) or indirect centrifugal inputs (Boyd et al., 2015; Otazu et al., 2015).

\section{Electrical stimulation of raphe increases tonic excitability in OB output neurons as reflected by calcium signals}

We next examined the impact of raphe stimulation on OB output neurons by expressing GCaMP5G or GCaMP6f in MT cells in PCdh21-cre mice via viral vector injected into aPC or directly into the OB (Rothermel et al., 2013; Wachowiak et al., 2013; Fig. $6 A)$. In contrast to its effects on PG and SA cells, in MT cells raphe stimulation did not significantly alter the magnitude of GCaMP transients linked to inhalation of ambient air (Fig. 6B), with inhalation-linked responses of $1.35 \pm 1.7 \% \Delta F / F$ prestimulation versus $1.12 \pm 1.78 \% \Delta F / F$ poststimulation (mean $\pm \mathrm{SD}, n=8$ mice; $p=0.875$, Wilcoxon signed ranks test). However, raphe stimulation strongly increased baseline fluorescence, which was not modulated by inhalation (Fig. 6B). In the three mice tested, raphe stimulation elicited a near-identical increase in GCaMP signal in the absence of artificial inhalation (Fig. 6B), suggesting that this effect reflects an increase in MT spiking independent of evoked sensory input to the OB.

These tonic increases reached peak magnitudes of $18 \pm 14 \%$ $\Delta F / F(n=8$ mice $)$, which were larger on average than the peak GCaMP signals evoked by odorant stimulation (ratio of peak raphe stimulation responses to peak odor responses, measured in each of seven mice tested with odorant, $1.47 \pm 0.77)$. GCaMP signals evoked by raphe stimulation were spread diffusely across the dorsal OB but were consistently largest in the caudal half (Fig. $6 C)$. The time course of the stimulation effect roughly matched that of the time course of enhanced PG and SA cell responses, with an onset time (time to $10 \%$ of peak levels) $550 \mathrm{~ms}$ after the beginning of stimulation and a decay time-constant of $\sim 8 \mathrm{~s}$ (Fig. 
A
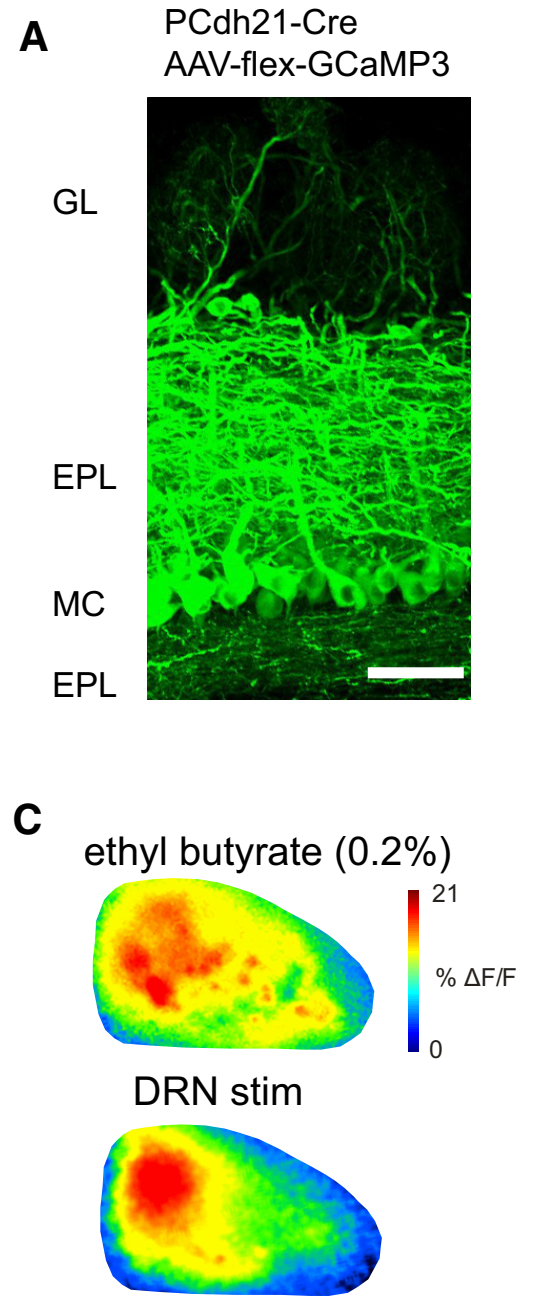

D

E

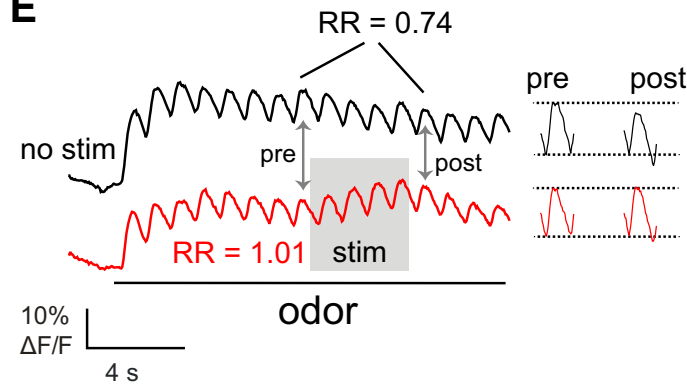

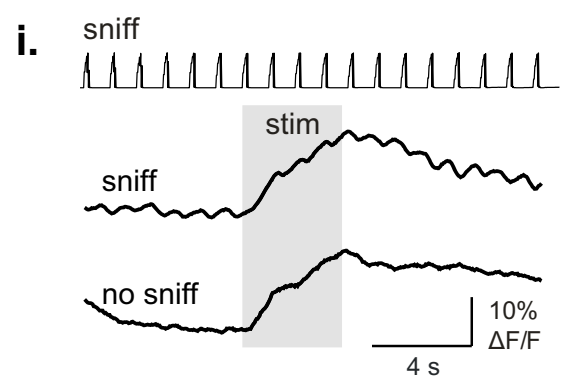

ii.

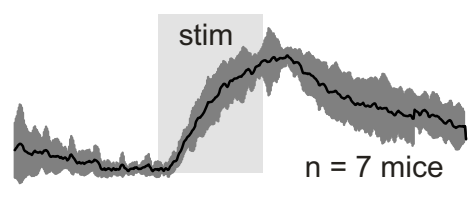

\section{shiff}
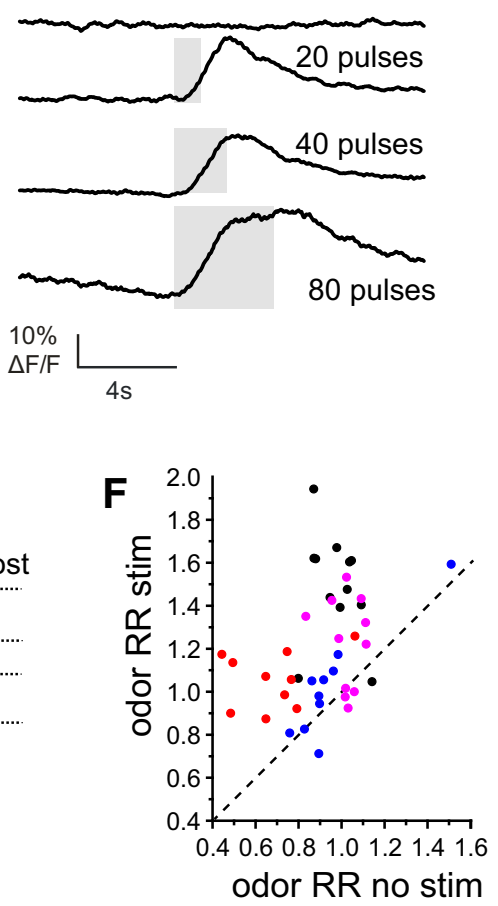

Figure 6. Raphe stimulation increases basal calcium signaling in mitral/tufted cells without affecting evoked sensory responses. A, Expression of GCaMP3 in OB MT cells after injection of AAV-flex-GCaMP3 into the anterior piriform cortex of a Pcdh21Cre mouse. Scale bar, $50 \mu \mathrm{m}$. Bi, Example of PCdh21+ fluorescence changes evoked by raphe stimulation during inhalation of ambient air (sniff) and in the same ROls in the absence of inhalation (no sniff). Note that the tonic fluorescence increase is nearly identical in the presence and absence of inhalation. Bii, Mean MT cell GCaMP signal elicited by raphe stimulation during inhalation of ambient air (sniff trace not shown), averaged across seven mice, showing gradual fluorescence increase and recovery with no apparent enhancement of inhalation-linked responses, in contrast to the effects seen in GAD2 + and TH+ neurons. $\boldsymbol{C}$, MT cell response maps elicited by odorant (top) and raphe stimulation during ambient air inhalation (bottom), with raphe stimulation eliciting a diffuse increase that was largest in the caudal OB.D. Example of PCdh21 + MT cell GCaMP signals elicited by raphe stimulus trains of increasing duration, with longer duration trains leading to slower recovery to baseline after the stimulation ceases but no emergence of inhalation-linked transients. $\boldsymbol{E}$, MT cell responses to raphe stimulation during odorant. Traces show GCaMP signals averaged across 10 odorant-responsive ROIs (ethyl butyrate, $0.2 \%$, s.v.) with and without raphe stimulation. Same mouse as shown in $\boldsymbol{C}$. Raphe stimulation elicits only a small fluorescence increase in the presence of odorant, with a very small increase in the amplitude of the inhalation-linked transient. Snippets of the response just before ("pre") and just after ("post") the stimulus train are shown to the right. $\boldsymbol{F}$, Scatter plot of odorant RR measured separately

6B). Also as with PG and SA cells, the magnitude and decay time of the rapheelicited increase was dependent on the duration of the stimulus train (Fig. $6 D$ ), with peak GCaMP signals increasing from $5.1 \pm 2.4 \Delta F / F$ after a 20 pulse (1 s) stimulus train to $35.2 \pm 2.7 \% \Delta F / F$ for an 80 pulse train $(n=3$ animals tested at each duration).

Despite its lack of significant effect on responses to inhalation of ambient air, raphe stimulation slightly increased inhalation-linked responses to odorant (Fig. 6F). Because a recent study reported heterogeneity of raphe stimulation effects among mitral cells (Kapoor et al., 2016), we quantified this effect by measuring odor RRs, as done for GAD2+ and TH+ neurons, separately for individual ROIs (8-12 ROIs per each of 4 mice; Fig. $6 G)$. Across all ROIs there was a significant increase in RR (increase of $0.26 \pm 0.27$, median $\pm \mathrm{SD} ; p=4.9 \times 10^{-9}, n=43$ ROIs, Wilcoxon signed ranks test), despite the relatively small increase in absolute amplitude of the inhalation-linked response. Thus, raphe stimulation appears to also modestly increase inhalation-linked responses to odorant across the MT cell population.

Optical activation of serotonergic raphe afferents to the $\mathrm{OB}$ has heterogeneous effects on individual MT cells

To directly examine the impact of raphe activation on $\mathrm{OB}$ neuron spiking patterns and to attribute $\mathrm{OB}$ modulation to activation of serotonergic neurons, we used an optogenetic approach to selectively activate serotonergic inputs from the raphe to the $\mathrm{OB}$ while recording from presumptive MT cells in the dorsal OB (Fig. 7A). To achieve this, we used Slc6a4-Cre mice (Gong et al., 2007) and a Cre-dependent viral vector driving Channelrhodopsin2 (ChR2-eYFP) expression in the raphe nuclei (see Materials and Methods). These injections infected raphe neurons in the midline below the central aqueduct, as well as in the typical wing-like structures of DRN extending into the periaqueductal gray (Fig. 7B). To evaluate infection efficiency, we injected virus in the F1 offspring of crosses between the Slc6a4-Cre line and the Rosa-tdTomato reporter line (Ai9), and evaluated coexpression of eYFP

$\leftarrow$

for $10-12$ Rols in each of four preparations $(0.2-0.5 \%$, s.v. ethyl butyrate, preparation indicated by color), showing a range of effects of raphe stimulation on odorant RR with most ROls showing an increase. 

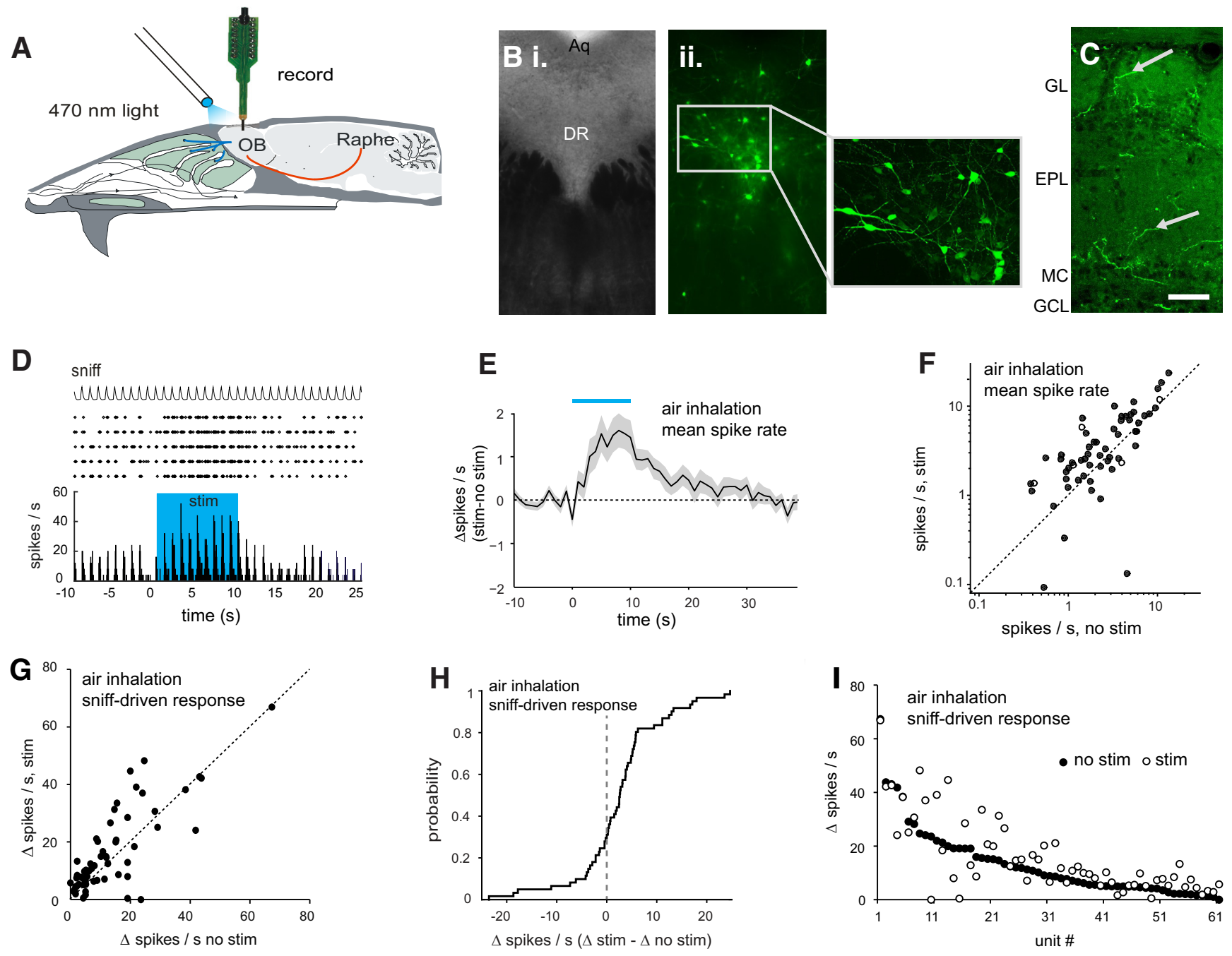

J i. no sniff
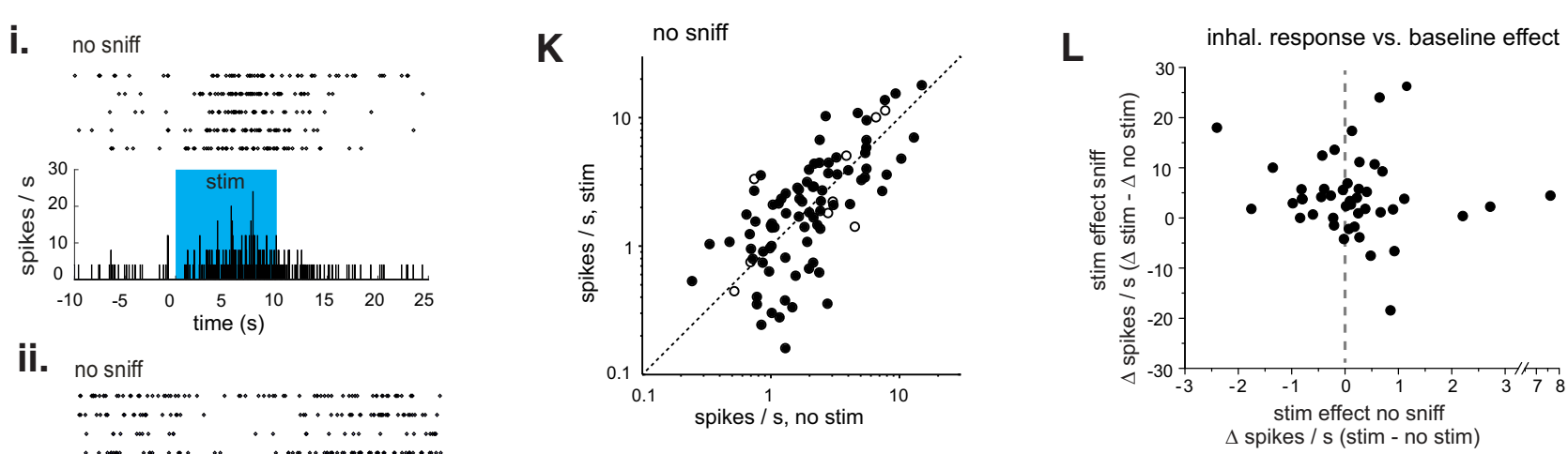

ii. no sniff
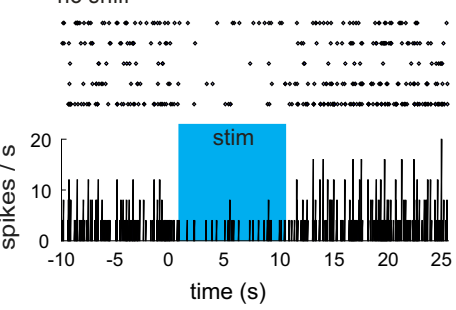

Figure 7. Optogenetic activation of serotonergic $O B$ afferents from raphe alters $M T$ cell excitation. $A$, Schematic of experimental approach for electrical recording of presumptive MT cells during optical stimulation of serotonergic projections to the OB. See Materials and Methods for details. $\boldsymbol{B}$, Images from midbrain tissue sections showing expression of CHR2-eYFP after injection of AAV-Flex-ChR2-eYFP into DRN of a Slc6a4-Cre mouse. Bi, Phase contrast bright-field image of region targeted for virus injection. Bii, Confocal image of the same section with higher-magnification of DRN region (inset, left) showing CHR2-eYFP expression in neurons throughout DRN. Aq, Cerebral aqueduct; DR, dorsal raphe. C, Confocal image taken from the OB showing eYFP expression in axonal fibers (arrows) in the glomerular and external plexiform layers, after injection of AAV-Flex-ChR2-eYFP into raphe. Scale bar, $50 \mu \mathrm{m}$. D, Spike raster and rate histogram showing spiking in a presumptive MT cell during inhalation of ambient air and optical stimulation (blue shaded area) in five repeated trials. Spike rate was calculated per $50 \mathrm{~ms}$ bin. Top trace (sniff) shows the time course of artificial inhalation. $E$, Time course of change in firing rate (mean $\pm S E M ; n=61$ units from 9 mice) during optical stimulation (blue bar). The trace indicates change in mean spike rate in $1 \mathrm{~s}$ bins relative to the mean rate before stimulation. The time axis is relative to time of stimulation onset. $\boldsymbol{F}$, Plot of MT cell firing rate averaged for the nine inhalations just before (Figure legend continues.) 
and tdTomato ( $n=3$ mice). Approximately 50\% (41.1-64.9\%, mean $53.5 \%, n=648$ neuron of 3 animals) of serotonergic DRN neurons showed eYFP expression after injection. Although DRN was targeted for injection, we also observed viral expression in the median raphe nucleus (data not shown), likely due to spread of virus from the injection site or to interconnections between the two nuclei (Mokler et al., 2009). For optical stimulation, we waited sufficient time for ChR2-eYFP expression in axonal fibers in the $\mathrm{OB}(21-70 \mathrm{~d}$; mean $=41 \mathrm{~d})$ and directed $470 \mathrm{~nm}$ light onto the dorsal $\mathrm{OB}$ surface while recording from presumptive MT cells. ChR2-eYFP-expressing axons were apparent in all OB layers, including in the glomerular layer (Fig. 7C).

We first investigated the effects of $\mathrm{OB}$ serotonergic activation on unit activity during inhalation of ambient air (no odor), including 61 units from nine mice (Fig. 7D). Across all units, optical serotonergic stimulation modestly increased baseline spiking: spike rates averaged across the $1 \mathrm{~s}$ inhalation period increased from $2.3 \pm 3.0$ (median $\pm \mathrm{SD})$ to $2.8 \pm 4.5 \mathrm{~Hz}$ with optogenetic stimulation $(p=8.5 \times$ $10^{-5}$, Wilcoxon signed rank test). The time course of the mean firing rate change across all recorded units consisted of a slow increase over the stimulation period that decayed slowly back to baseline $\sim 20 \mathrm{~s}$ after stimulation ceased (Fig. $7 E$ ). Stimulation effects varied across units (Fig. $7 F$ ): in 56 of the 61 units, stimulation was repeated in a sufficient number of trials to support a test of significance on each unit (criterion, $n \geq 5$ trials; all other units tested with $n \geq 3$ trials). Nineteen of 56 (34\%) showed statistically significant changes in firing rate (spikes per sniff, Mann-Whitney $U$ test) when tested on a unit-by-unit basis. Of those, three $(15.8 \%)$ were significantly inhibited.

To assay the effects of serotonergic activation on sensory-evoked MT responses (as opposed to tonic activity), we analyzed the same data for stimulation effects on the magnitude of the inhalationlinked spike burst, measured as the change in spike rate $(\Delta \mathrm{Hz})$ from baseline (defined as the $100 \mathrm{~ms}$ bin before artificial inhalation onset) to the peak response bin. These effects were also variable: across all units inhalation-linked responses increased slightly in magnitude from $8.9 \pm 12.9$ to $10.2 \pm 14.26 \Delta \mathrm{Hz}$ (median $\pm \mathrm{SD}, p=0.0024$, Wilcoxon signed rank test), with $\sim 30 \%$ of units showing decreases or no change in response (Fig. $7 G, H$ ). There was no clear relationship between the effect of optical serotonergic activation on responses and the magnitude of the inhalation-linked response in the absence of stimulation (Fig. 7I).

\section{$\leftarrow$}

(Figure legend continued.) （no stim) and after (stim) optical stimulation for all 61 units. Filled circles indicate units subjected to a unit-by-unit test for significant effects of optical stimulation ( 5 trials per condition per unit). Open circles indicate units tested with three trials. G, Plot of the amplitude of the inhalation-linked spike burst during inhalation of ambient air (measured as change in firing rate relative to pre-inhalation baseline; see Materials and Methods for details) in the presence and absence of optical stimulation. $\boldsymbol{H}$, Cumulative probability plot of the effect of optical stimulation on inhalation-linked responses, taken from same data shown in $\mathbf{G}$. Note distribution of increases and decreases in firing rate with a bias toward firing rate increases. I, Same data as in $\mathbf{G}$, with units ordered on the $x$-axis by the magnitude of their inhalation-linked response without optical stimulation (no stim, filled circles). Effects of optical stimulation (open circles) vary and are not obviously related to the magnitude of the inhalation-linked spike burst. $\boldsymbol{J}$, Spike rasters and rate histograms showing examples from two units (Ji and Jii) of effects of optically stimulating serotonergic $O B$ afferents on spontaneous activity, measured in the absence of inhalation (no sniff). Note qualitatively different effects in these two units. $\boldsymbol{K}$, Plot of spontaneous spike rates in the absence (no stim) and presence (stim) of optical stimulation ( $n=95$ units, 6 mice,) plotted as in F. L, Effects of optical stimulation on baseline MT cell spiking in the absence of inhalation (stim no sniff) versus effects on inhalation-linked spiking (stim sniff) in the same unit, plotted for the subset of the units in $\boldsymbol{I}$ and $\boldsymbol{K}$ in which stimulation effects could be measured under both conditions.
To assess serotonergic afferent effects on tonic (ie, nonsensory-evoked) MT activity, we stimulated serotonergic raphe afferents in the absence of artificial inhalation ( 95 units from 6 mice). Under these conditions, optical stimulation also had diverse effects that included both increases and decreases (Fig. $7 J, K)$. On a unit-by-unit basis, 27 of 84 units tested with five or more trials $(32 \%)$ showed statistically significant changes in firing rate, with 12 units activated and 15 inhibited (Mann-Whitney $U$ test). Across all units there was no significant change in firing rate $(1.9 \pm 2.7 \mathrm{~Hz}$ vs $1.9 \pm 3.4 \mathrm{~Hz} ; n=84$ units, median \pm $\mathrm{SD} ; p=0.18$, Wilcoxon signed rank test). There was also no correlation, on a unit-by-unit basis, between the effect of serotonergic raphe stimulation on tonic MT activity and its effect on the same unit's response to air inhalation (Fig. $7 L ; n=34$ units, Spearman's $\rho=-0.085, p=0.58$ ).

Finally, we evaluated the impact of $\mathrm{OB}$ serotonergic activation on odorant-evoked responses ( $n=74$ units from 11 mice). Odorant presentation alone could elicit increases or decreases in spiking among presumptive MT cells (Fig. 8A). The effects of serotonergic stimulation on these responses were variable but, across all units, consisted of an increase in spike rate from $0.16 \pm 3.9$ (median \pm SD) to $2 \pm 7.1 \Delta \mathrm{Hz}\left(n=74, p=5 \times 10^{-10}\right.$, Wilcoxon signed rank test). Spike rate increases occurred regardless of the polarity of the odorant response (Fig. $8 B$ ). The enhancement of odorantevoked MT cell responses began within $1 \mathrm{~s}$ of stimulation onset, persisted for the duration of the optical stimulation, and gradually returned to prestimulation levels within $40 \mathrm{~s}$ after the end of optical stimulation (Fig. 8C). Separately measuring the effects of serotonergic afferent stimulation on the magnitude of the inhalation-linked component of the odorant response (Fig. $8 D, E$ ) yielded similar results, with heterogeneity in stimulation effects and modest increases in inhalationlinked spike rates across all units from $11.6 \pm 18.0$ to $14.6 \pm$ 21.7 $\Delta \mathrm{Hz}(n=74$, median $\pm \mathrm{SD}, p=0.0011$, Wilcoxon signed rank test). As observed with air inhalation, there was no correlation between the stimulation effect on tonic MT firing rate and its effect on the same unit's response to odorant (Fig. 8F; $n=20$ units; Spearman's $\rho=0.0262, p=0.91$ ). Overall, these results are consistent with recent findings and suggest that activation of serotonergic afferents from raphe has diverse effects on resting and evoked MT cell activity, with a modest increase in excitation across the MT cell population (Kapoor et al., 2016).

\section{Discussion}

Neuromodulatory systems can alter sensory processing by targeting specific elements of central sensory networks. For example, serotonergic modulation alters the balance of excitation and inhibition in visual cortex by differentially modulating distinct cell types (Xiang and Prince, 2003; Moreau et al., 2010). Likewise, serotonergic projections from the midbrain raphe nuclei strongly innervate the $\mathrm{OB}$ and 5-HT modulates tonic and evoked activity within OB circuits (Hardy et al., 2005; Petzold et al., 2009; Liu et al., 2012; Brill et al., 2016). At the level of OB output neurons, we observed an increase in tonic (ie, not sensory evoked) levels of MT cell activity driven by serotonergic raphe activation, with heterogeneous effects on the response of individual MT cells to input driven either by odorant or air inhalation; results that largely agree with those from a recent study characterizing modulation of mitral and tufted cell excitability by raphe (Kapoor et al., 2016). In addition, we have extended these findings by demonstrating that raphe afferents mediate a dramatic enhancement of the responsiveness of two distinct classes of inhibitory in- 
A i.

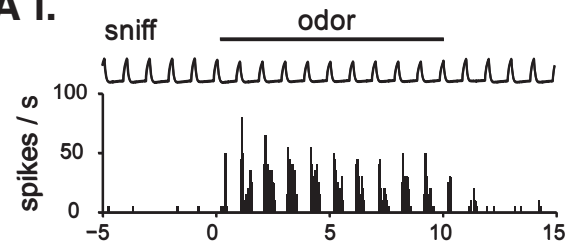

odor + stim

lohaharararahah

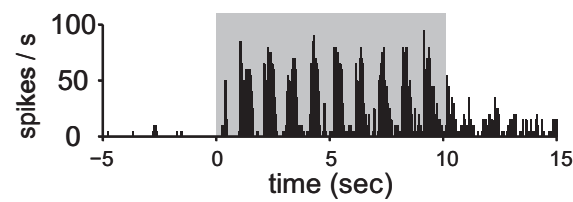

B

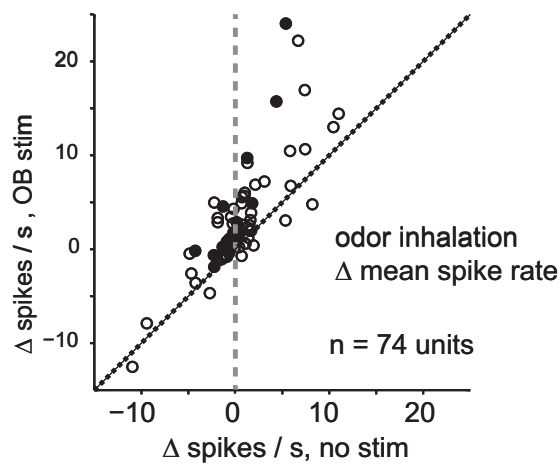

D
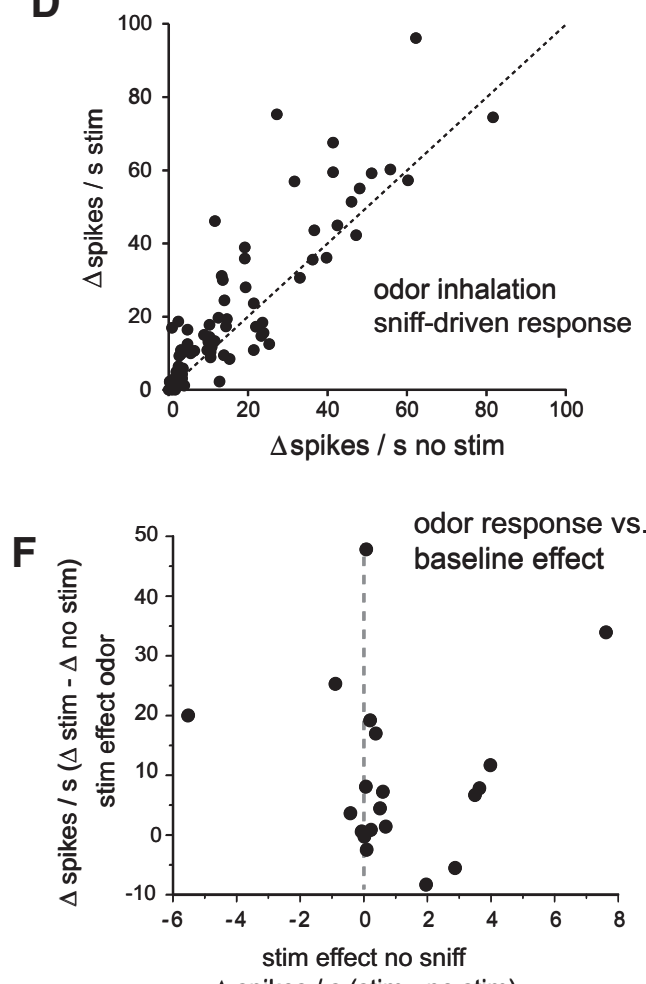

ii.

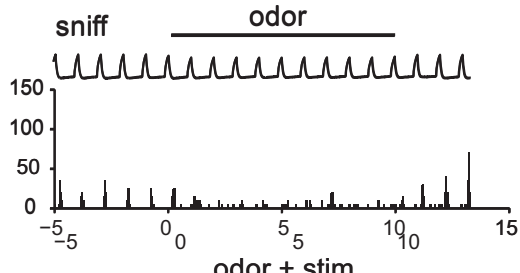

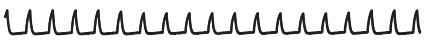

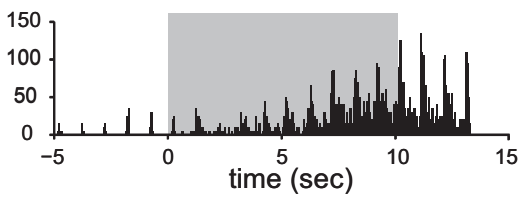

C

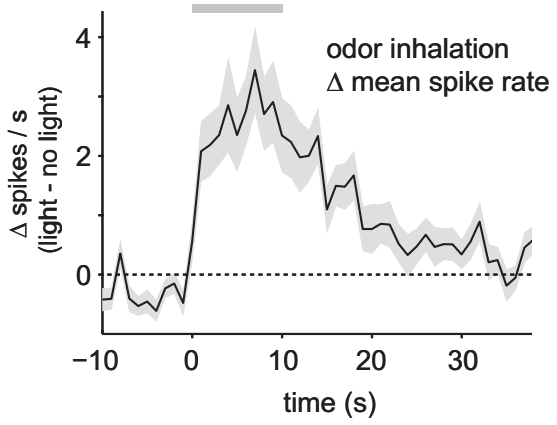

E

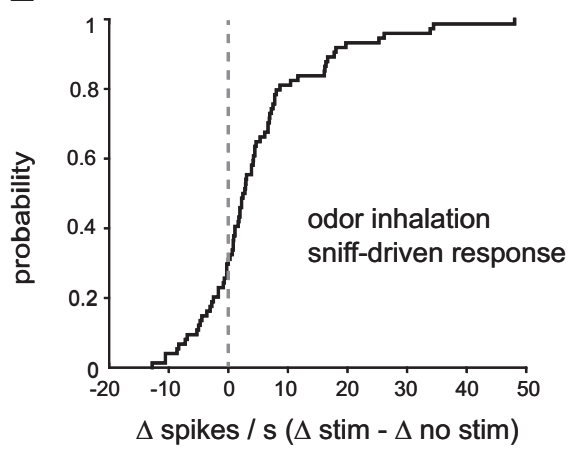

Figure 8. Optogenetic activation of serotonergic $O B$ afferents from raphe modestly enhances odor responses in presumptive MT cells. $A$, Examples of effect of optical stimulation on odorantevoked responses in two different units. Top, Rate histograms (mean of 5 trials) in the absence of optical stimulation; bottom show the same data with optical stimulation simultaneous with odorant presentation. The first unit (Ai) shows strong odorant-evoked excitation which is increased during stimulation of serotonergic afferents (odorant, isoamyl acetate); the second unit (Aii) shows odorant-evoked suppression of activity, which transforms into excitation during optical stimulation (odorant, ethyl butyrate). $\boldsymbol{B}$, Plot of odorant-evoked changes in spike rate ( $\Delta$ spikes/s) in the absence of (no stim) and during (stim) optogenetic stimulation of raphe fibers to the OB. Filled circles indicate units tested with five or more trials in each condition; (Figure legend continues.) 
terneurons, PG and SA cells, to inhalation-driven sensory input, thus implicating the raphe system in dynamically modulating the balance of excitation and inhibition in the OB.

Our results support an emerging circuit model of raphe modulation that involves increased excitation of ET cells, a class of excitatory, glutamatergic glomerular-layer interneuron that provides excitatory drive to PG, SA, and MT cells (Hayar et al., 2004; Gire et al., 2012). ET cells burst intrinsically, entrain to rhythmic sensory inputs in the range of inhalation frequencies seen in the behaving rodent, and are thought play a key role in the temporal patterning of glomerular activity during natural odor sampling (Hayar et al., 2004; Liu et al., 2012). In vitro, 5-HT depolarizes ET cells and increases their intrinsic bursting frequency (Liu et al., 2012), and selective activation of raphe afferents to the OB drives short-latency excitation of ET cells (Kapoor et al., 2016). Consistent with this model, we found that raphe-mediated enhancement of sensory-evoked (ie, inhalation-linked) PG and SA cell excitation appeared largely driven by an increase in glutamatergic input to these neurons, as revealed by imaging with the optical glutamate sensor iGluSnFR. Imaging from the MT cell population did not show a raphe-mediated increase in inhalation-linked responses in the same conditions, excluding MT cells as a potential source for the phasic glutamate release onto PG and SA cells. We thus speculate that modulation of ET cell excitability and these neurons' entrainment to inhalation is the primary source of the dramatic increase in evoked PG and SA cell responses.

It is unclear from this model why raphe stimulation did not lead to a comparable enhancement of inhalation-linked excitation of MT cells, because ET cells also provide a major source of excitatory input to MT cells (De Saint Jan et al., 2009; Gire et al., 2012; Banerjee et al., 2015). One explanation is that MT cells also receive potent tonic and sensory-evoked feedforward inhibition from PG cells (Shao et al., 2012), and we found that both tonic and sensory-evoked PG cell activity is enhanced by raphe stimulation, leading to the prediction that raphe afferents enhance the strength of feedforward inhibition. A second possibility is that the enhanced SA cell sensory responses which were also elicited by raphe stimulation may suppress strong MT responses, as demonstrated recently in vivo, through a mixture of inhibitory synaptic input and excitatory coupling to ET cells (Liu et al., 2013; Whitesell et al., 2013; Banerjee et al., 2015). Thus, raphe stimulation could lead to enhancement, suppression or no net change in MT responsiveness depending on the relative balance of ET celldriven, feedforward excitation versus inhibition in each cell and the relative timing of activation of these pathways. As a result, the net population effect observed in the epifluorescence imaging experiments could be small. Consistent with this explanation, we observed mixed effects of optogenetic activation of serotonergic raphe neurons on presumptive MT cells recorded electrophysi-

\section{$\leftarrow$}

(Figure legend continued.) open circles indicate units tested with three or four trials. C, Time course of change in firing rate caused by optical stimulation ( $\Delta$ spikes/s with optical stimulation vs without optical stimulation; mean \pm SEM across all units). Gray bar indicates timing of optical stimulation. The trace indicates change in mean spike rate in $1 \mathrm{sbins}$ relative to the mean rate before stimulation. Time axis is relative to time of stimulation onset. $\boldsymbol{D}$, Plot of the amplitude of the inhalation-linked spike burst during inhalation of odorant (measured as change in firing rate relative to pre-inhalation baseline) in the presence and absence of optical stimulation. $E$, Cumulative probability plot of the effect of optical stimulation on inhalation-linked responses, taken from same data shown in $\boldsymbol{D}$. $\boldsymbol{F}$, Effects of optical stimulation on baseline MT cell spiking in the absence of inhalation ("stim effect no sniff") versus effects on odorant-evoked responses ("stim effect odor") in the same unit, plotted for the subset of the units in which stimulation effects could be measured under both conditions. ologically, as did a recent study imaging odor responses from visually identified mitral cells (Kapoor et al., 2016).

\section{Mechanisms of raphe modulation of $\mathrm{OB}$ circuits}

Raphe afferents may modulate $\mathrm{OB}$ circuits via multiple neurotransmitter signaling pathways. Specifically, serotonergic raphe neurons can also release glutamate (Liu et al., 2014), and Kapoor et al. (2016) suggested that the raphe-mediated enhancement of ET cell excitability central to the model described above is mediated largely by glutamatergic input to ET cells from raphe afferents (Kapoor et al., 2016). At the same time, exogenous application of 5-HT in vitro also enhances ET cell excitation and increases mitral cell spontaneous activity (Liu et al., 2012), as well as directly modulates resting potential and synaptic release from SA cells, and possibly other juxtaglomerular interneurons (Hardy et al., 2005; Brill et al., 2016). We found that the effects of raphe activation on PG and SA cell responses were only partially suppressed by 5 -HT receptor blockade in vivo. However, this partial suppression does imply a role for serotonergic signaling in modulating $\mathrm{OB}$ circuits, and the fact that raphe-mediated modulation outlasted our relatively brief stimulus train by many seconds is more consistent with serotonergic modulation than with fast glutamatergic transmission. Thus, our results are consistent with a role for both glutamatergic and serotonergic signaling pathways in mediating the effects of raphe stimulation on OB circuits.

The relative contribution of glutamatergic and serotonergic signaling and their resulting impacts on different $\mathrm{OB}$ circuit elements may vary with the timescale and intensity of raphe activation. For example, the standard $4 \mathrm{~s}$ stimulus trains used in the bulk of our experiments led to enhanced PG and SA cell responses lasting several seconds beyond the end of the stimulus train, whereas a 3 pulse (200 ms total duration) train (Kapoor et al., 2016) caused a much smaller enhancement lasting only 2-3 s (Figs. 1E, 2E). Likewise, prolonged (30 s-10 min) raphe stimulation protocols have been reported to lead to suppression of sensory inputs via presynaptic inhibition of OSNs (Petzold et al., 2009), an effect opposite from the enhanced sensory responses seen here. These different timescales of raphe activation may reflect distinct modulatory actions of the raphe system on early olfactory processing during different behavioral contexts such as social interaction or anxiety (Ago et al., 2013; Ohmura et al., 2014; Zhang et al., 2015).

Differences in the mode of serotonergic stimulation may also lead to different effects on OB neuron responses. For example, electrical stimulation targeting DRN, as done in our imaging experiments and by Petzold et al. (2009), likely activated a set of serotonergic $\mathrm{OB}$ afferents that was overlapping but distinct from those activated by optical stimulation of the dorsal OB surface after viral injections into DRN/MRN, because DRN and MRN projections preferentially target the granule cell and glomerular layers, respectively (Steinfeld et al., 2015) and optical stimulation from the dorsal surface may also exhibit a bias toward superficial (eg, glomerular layer) fibers. Electrical stimulation of raphe may also modulate structures including piriform cortex and anterior olfactory nucleus which themselves can modulate $\mathrm{OB}$ circuits via centrifugal inputs (Boyd et al., 2012, 2015; Markopoulos et al., 2012; Rothermel et al., 2014; Otazu et al., 2015; Lottem et al., 2016). Finally, odorant stimulation itself may activate raphe neurons, thus changing the baseline from which modulation occurs when raphe is stimulated in the presence of absence of odorant. Recording from dorsal and median raphe afferents to the $\mathrm{OB}$ under these different stimulation conditions may be important in 
unraveling the diversity of modulatory effects seen in this and other recent studies.

\section{Potential roles of raphe in shaping early olfactory processing}

Overall, these results underscore the complexity of serotonergic modulation of $\mathrm{OB}$ circuits and the potential for dynamic modulation of odor processing by the descending serotonergic system during behavior. Despite this complexity, these results along with recent in vivo and in vitro studies (Liu et al., 2012; Brill et al., 2016; Kapoor et al., 2016) suggest a consensus circuit model in which raphe modulation leads to enhanced ET cell responsiveness and, through both indirect and direct effects, to enhanced PG and SA cell responses to sensory input. One prediction from this model is that serotonergic modulation may increase the degree to which disynaptic excitation via ET cells and inhibition by PG and SA cells shapes OB output, and decrease the degree to which monosynaptic excitation via OSNs shapes output. Such modulation could enhance the temporal coupling of mitral cell responses to the sniff cycle during active odor sampling (Shao et al., 2012, 2013; Carey et al., 2015). This change in the strength of feedforward and interglomerular inhibition may alter mitral cell response patterns in manner that facilitates fine odor discrimination and increases dynamic range across concentrations (Banerjee et al., 2015). Finally, the net effects of raphe modulation on OB output may also vary with the intensity of sensory input, and potentially, spatial patterns of glomerular activity. For example, for weak sensory inputs such as those driven by inhalation of ambient air or low odorant concentrations, raphe modulation enhances sensory responses of ET cells, leading to increased in PG and SA cell responses and to mixed effects on MT cells. During stimulation by stronger odor concentrations, however, near-maximal responses of ET, PG, and SA cells may preclude any further enhancement by raphe inputs, with a result that direct serotonergic effects on MT cells, or other as yet unknown circuit effects, predominate. Ultimately, further recordings from defined cell types during activation of serotonergic $\mathrm{OB}$ afferents in awake mice will be important to test these predictions.

\section{References}

Ago Y, Araki R, Tanaka T, Sasaga A, Nishiyama S, Takuma K, Matsuda T (2013) Role of social encounter-induced activation of prefrontal serotonergic systems in the abnormal behaviors of isolation-reared mice. Neuropsychopharmacology 38:1535-1547. CrossRef Medline

Akerboom J, Chen TW, Wardill TJ, Tian L, Marvin JS, Mutlu S, Calderón NC, Esposti F, Borghuis BG, Sun XR, Gordus A, Orger MB, Portugues R, Engert F, Macklin JJ, Filosa A, Aggarwal A, Kerr RA, Takagi R, Kracun S, et al. (2012) Optimization of a GCaMP calcium indicator for neural activity imaging. J Neurosci 32:13819-13840. CrossRef Medline

Banerjee A, Marbach F, Anselmi F, Koh MS, Davis MB, Garcia da Silva P, Delevich K, Oyibo HK, Gupta P, Li B, Albeanu DF (2015) An interglomerular circuit gates glomerular output and implements gain control in the mouse olfactory bulb. Neuron 87:193-207. CrossRef Medline

Boyd AM, Sturgill JF, Poo C, Isaacson JS (2012) Cortical feedback control of olfactory bulb circuits. Neuron 76:1161-1174. CrossRef Medline

Boyd AM, Kato HK, Komiyama T, Isaacson JS (2015) Broadcasting of cortical activity to the olfactory bulb. Cell Rep 10:1032-1039. CrossRef Medline

Bozza T, McGann JP, Mombaerts P, Wachowiak M (2004) In vivo imaging of neuronal activity by targeted expression of a genetically encoded probe in the mouse. Neuron 42:9-21. CrossRef Medline

Brill J, Shao Z, Puche AC, Wachowiak M, Shipley MT (2016) Serotonin increases synaptic activity in olfactory bulb glomeruli. J Neurophysiol 115:1208-1219. CrossRef Medline

Carey RM, Wachowiak M (2011) Effect of sniffing on the temporal structure of mitral/tufted cell output from the olfactory bulb. J Neurosci 31: 10615-10626. CrossRef Medline

Carey RM, Verhagen JV, Wesson DW, Pírez N, Wachowiak M (2009) Temporal structure of receptor neuron input to the olfactory bulb imaged in behaving rats. J Neurophysiol 101:1073-1088. Medline
Carey RM, Sherwood WE, Shipley MT, Borisyuk A, Wachowiak M (2015) Role of intraglomerular circuits in shaping temporally structured responses to naturalistic inhalation-driven sensory input to the olfactory bulb. J Neurophysiol 113:3112-3129. CrossRef Medline

Cazakoff BN, Lau BY, Crump KL, Demmer HS, Shea SD (2014) Broadly tuned and respiration-independent inhibition in the olfactory bulb of awake mice. Nat Neurosci 17:569-576. CrossRef Medline

Chen TW, Wardill TJ, Sun Y, Pulver SR, Renninger SL, Baohan A, Schreiter ER, Kerr RA, Orger MB, Jayaraman V, Looger LL, Svoboda K, Kim DS (2013) Ultra-sensitive fluorescent proteins for imaging neuronal activity. Nature 499:295-300. CrossRef Medline

De Saint Jan D, Hirnet D, Westbrook GL, Charpak S (2009) External tufted cells drive the output of olfactory bulb glomeruli. J Neurosci 29:20432052. CrossRef Medline

Dugué GP, Lörincz ML, Lottem E, Audero E, Matias S, Correia PA, Léna C, Mainen ZF (2014) Optogenetic recruitment of dorsal raphe serotonergic neurons acutely decreases mechanosensory responsivity in behaving mice. PLoS One 9:e105941. CrossRef Medline

Enger R, Tang W, Vindedal GF, Jensen V, Johannes Helm P, Sprengel R, Looger LL, Nagelhus EA (2015) Dynamics of ionic shifts in cortical spreading depression. Cereb Cortex 25:4469-4476. CrossRef Medline

Fukunaga I, Herb JT, Kollo M, Boyden ES, Schaefer AT (2014) Independent control of gamma and theta activity by distinct interneuron networks in the olfactory bulb. Nat Neurosci 17:1208-1216. CrossRef Medline

Gire DH, Franks KM, Zak JD, Tanaka KF, Whitesell JD, Mulligan AA, Hen R, Schoppa NE (2012) Mitral cells in the olfactory bulb are mainly excited through a multistep signaling path. J Neurosci 32:2964-2975. CrossRef Medline

Gong S, Doughty M, Harbaugh CR, Cummins A, Hatten ME, Heintz N, Gerfen CR (2007) Targeting Cre recombinase to specific neuron populations with bacterial artificial chromosome constructs. J Neurosci 27: 9817-9823. CrossRef Medline

Grosmaitre X, Santarelli LC, Tan J, Luo M, Ma M (2007) Dual functions of mammalian olfactory sensory neurons as odor detectors and mechanical sensors. Nat Neurosci 10:348-354. CrossRef Medline

Hardy A, Palouzier-Paulignan B, Duchamp A, Royet JP, Duchamp-Viret P (2005) 5-Hydroxytryptamine action in the rat olfactory bulb: in vitro electrophysiological patch-clamp recordings of juxtaglomerular and mitral cells. Neuroscience 131:717-731. CrossRef Medline

Hayar A, Karnup S, Ennis M, Shipley MT (2004) External tufted cells: a major excitatory element that coordinates glomerular activity. J Neurosci 24:6676-6685. CrossRef Medline

Hurley LM, Sullivan MR (2012) From behavioral context to receptors: serotonergic modulatory pathways in the IC. Front Neural Circuits 6:58. CrossRef Medline

Hurley LM, Devilbiss DM, Waterhouse BD (2004) A matter of focus: monoaminergic modulation of stimulus coding in mammalian sensory networks. Curr Opin Neurobiol 14:488-495. CrossRef Medline

Ichikawa T, Hirata Y (1986) Organization of choline acetyltransferase-containing structures in the forebrain of the rat. J Neurosci 6:281-292. Medline

Isaacson JS (1999) Glutamate spillover mediates excitatory transmission in the rat olfactory bulb. Neuron 23:377-384. CrossRef Medline

Jacobs BL, Azmitia EC (1992) Structure and function of the brain serotonin system. Physiol Rev 72:165-229. Medline

Jacobs BL, Fornal CA (1997) Serotonin and motor activity. Curr Opin Neurobiol 7:820-825. CrossRef Medline

Jacobs BL, Fornal CA (1999) Activity of serotonergic neurons in behaving animals. Neuropsychopharmacology 21:9S-15S. CrossRef Medline

Kapoor V, Provost AC, Agarwal P, Murthy VN (2016) Activation of raphe nuclei triggers rapid and distinct effects on parallel olfactory bulb output channels. Nat Neurosci 19:271-282. CrossRef Medline

Kato HK, Chu MW, Isaacson JS, Komiyama T (2012) Dynamic sensory representations in the olfactory bulb: modulation by wakefulness and experience. Neuron 76:962-975. CrossRef Medline

Kiyokage E, Pan YZ, Shao Z, Kobayashi K, Szabo G, Yanagawa Y, Obata K, Okano H, Toida K, Puche AC, Shipley MT (2010) Molecular identity of periglomerular and short axon cells. J Neurosci 30:1185-1196. CrossRef Medline

Kosaka T, Kosaka K (2008) Tyrosine hydroxylase-positive GABAergic juxtaglomerular neurons are the main source of the interglomerular connections in the mouse main olfactory bulb. Neurosci Res 60:349-354. CrossRef Medline

Liu S, Aungst JL, Puche AC, Shipley MT (2012) Serotonin modulates the population activity profile of olfactory bulb external tufted cells. J Neurophysiol 107:473-483. CrossRef Medline 
Liu S, Plachez C, Shao Z, Puche A, Shipley MT (2013) Olfactory bulb short axon cell release of GABA and dopamine produces a temporally biphasic inhibition-excitation response in external tufted cells. J Neurosci 33: 2916-2926. CrossRef Medline

Liu S, Shao Z, Puche A, Wachowiak M, Rothermel M, Shipley MT (2015) Muscarinic receptors modulate dendrodendritic inhibitory synapses to sculpt glomerular output. J Neurosci 35:5680-5692. CrossRef Medline

Liu Z, Zhou J, Li Y, Hu F, Lu Y, Ma M, Feng Q, Zhang JE, Wang D, Zeng J, Bao J, Kim JY, Chen ZF, El Mestikawy S, Luo M (2014) Dorsal raphe neurons signal reward through 5-HT and glutamate. Neuron 81:1360-1374. CrossRef Medline

Lottem E, Lörincz ML, Mainen ZF (2016) Optogenetic activation of dorsal raphe serotonin neurons rapidly inhibits spontaneous but not odorevoked activity in olfactory cortex. J Neurosci 36:7-18. CrossRef Medline

Madisen L, Zwingman TA, Sunkin SM, Oh SW, Zariwala HA, Gu H, Ng LL, Palmiter RD, Hawrylycz MJ, Jones AR, Lein ES, Zeng H (2010) A robust and high-throughput Cre reporting and characterization system for the whole mouse brain. Nat Neurosci 13:133-140. CrossRef Medline

Markopoulos F, Rokni D, Gire DH, Murthy VN (2012) Functional properties of cortical feedback projections to the olfactory bulb. Neuron 76: 1175-1188. CrossRef Medline

Marvin JS, Borghuis BG, Tian L, Cichon J, Harnett MT, Akerboom J, Gordus A, Renninger SL, Chen TW, Bargmann CI, Orger MB, Schreiter ER, Demb JB, Gan WB, Hires SA, Looger LL (2013) An optimized fluorescent probe for visualizing glutamate neurotransmission. Nat Methods 10:162-170. CrossRef Medline

McGann JP, Pírez N, Gainey MA, Muratore C, Elias AS, Wachowiak M (2005) Odorant representations are modulated by intra- but not interglomerular presynaptic inhibition of olfactory sensory neurons. Neuron 48:1039-1053.

McLean JH, Shipley MT (1987) Serotonergic afferents to the rat olfactory bulb: I. Origins and laminar specificity of serotonergic inputs in the adult rat. J Neurosci 7:3016-3028. Medline

McLean JH, Shipley MT, Nickell WT, Aston-Jones G, Reyher CK (1989) Chemoanatomical organization of the noradrenergic input from locus coeruleus to the olfactory bulb of the adult rat. J Comp Neurol 285: 339-349. CrossRef Medline

Mokler DJ, Dugal JR, Hoffman JM, Morgane PJ (2009) Functional interrelations between nucleus raphe dorsalis and nucleus raphe medianus: a dual probe microdialysis study of glutamate-stimulated serotonin release. Brain Res Bull 78:132-138. CrossRef Medline

Monti JM (2011) Serotonin control of sleep-wake behavior. Sleep Med Rev 15:269-281. CrossRef Medline

Moreau AW, Amar M, Le Roux N, Morel N, Fossier P (2010) Serotoninergic fine-tuning of the excitation-inhibition balance in rat visual cortical networks. Cereb Cortex 20:456-467. CrossRef Medline

Nagai Y, Sano H, Yokoi M (2005) Transgenic expression of Cre recombinase in mitral/tufted cells of the olfactory bulb. Genesis 43:12-16. CrossRef Medline

Najac M, Sanz Diez A, Kumar A, Benito N, Charpak S, De Saint Jan D (2015) Intraglomerular lateral inhibition promotes spike timing variability in principal neurons of the olfactory bulb. J Neurosci 35:4319-4331. CrossRef Medline

Nunez-Parra A, Maurer RK, Krahe K, Smith RS, Araneda RC (2013) Disruption of centrifugal inhibition to olfactory bulb granule cells impairs olfactory discrimination. Proc Natl Acad Sci U S A 110:14777-14782. CrossRef Medline

Ohmura Y, Tanaka KF, Tsunematsu T, Yamanaka A, Yoshioka M (2014) Optogenetic activation of serotonergic neurons enhances anxiety-like behaviour in mice. Int J Neuropsychopharmacol 17:1777-1783. CrossRef Medline

Ojima H, Yamasaki T, Kojima H, Akashi A (1988) Cholinergic innervation of the main and the accessory olfactory bulbs of the rat as revealed by a monoclonal antibody against choline acetyltransferase. Anat Embryol 178:481-488. CrossRef Medline

Otazu GH, Chae H, Davis MB, Albeanu DF (2015) Cortical feedback decorrelates olfactory bulb output in awake mice. Neuron 86:1461-1477. CrossRef Medline

Petzold GC, Hagiwara A, Murthy VN (2009) Serotonergic modulation of odor input to the mammalian olfactory bulb. Nat Neurosci 12:784-791. CrossRef Medline

Ranade SP, Mainen ZF (2009) Transient firing of dorsal raphe neurons en- codes diverse and specific sensory, motor, and reward events. J Neurophysiol 102:3026-3037. CrossRef Medline

Rothermel M, Brunert D, Zabawa C, Díaz-Quesada M, Wachowiak M (2013) Transgene expression in target-defined neuron populations mediated by retrograde infection with adeno-associated viral vectors. J Neurosci 33:15195-15206. CrossRef Medline

Rothermel M, Carey RM, Puche A, Shipley MT, Wachowiak M (2014) Cholinergic inputs from basal forebrain add an excitatory bias to odor coding in the olfactory bulb. J Neurosci 34:4654-4664. CrossRef Medline

Schmidt LJ, Strowbridge BW (2014) Modulation of olfactory bulb network activity by serotonin: synchronous inhibition of mitral cells mediated by spatially localized GABAergic microcircuits. Learn Mem 21:406-416. CrossRef Medline

Shao Z, Puche AC, Liu S, Shipley MT (2012) Intraglomerular inhibition shapes the strength and temporal structure of glomerular output. J Neurophysiol 108:782-793. CrossRef Medline

Shao Z, Puche AC, Shipley MT (2013) Intraglomerular inhibition maintains mitral cell response contrast across input frequencies. J Neurophysiol 110:2185-2191. CrossRef Medline

Shea SD, Katz LC, Mooney R (2008) Noradrenergic induction of odorspecific neural habituation and olfactory memories. J Neurosci 28:1071110719. CrossRef Medline

Shipley MT, Halloran FJ, de la Torre J (1985) Surprisingly rich projection from locus coeruleus to the olfactory bulb in the rat. Brain Res 329: 294-299. CrossRef Medline

Spors H, Wachowiak M, Cohen LB, Friedrich RW (2006) Temporal dynamics and latency patterns of receptor neuron input to the olfactory bulb. J Neurosci 26:1247-1259. CrossRef Medline

Steinfeld R, Herb JT, Sprengel R, Schaefer AT, Fukunaga I (2015) Divergent innervation of the olfactory bulb by distinct raphe nuclei. J Comp Neurol 523:805-813. CrossRef Medline

Taniguchi H, He M, Wu P, Kim S, Paik R, Sugino K, Kvitsani D, Fu Y, Lu J, Lin Y, Miyoshi G, Shima Y, Fishell G, Nelson SB, Huang ZJ (2011) A resource of cre driver lines for genetic targeting of GABAergic neurons in cerebral cortex. Neuron 71:995-1013. CrossRef Medline

Tian L, Hires SA, Mao T, Huber D, Chiappe ME, Chalasani SH, Petreanu L, Akerboom J, McKinney SA, Schreiter ER, Bargmann CI, Jayaraman V, Svoboda K, Looger LL (2009) Imaging neural activity in worms, flies and mice with improved GCaMP calcium indicators. Nat Methods 6:875-881.

Verhagen JV, Wesson DW, Netoff TI, White JA, Wachowiak M (2007) Sniffing controls an adaptive filter of sensory input to the olfactory bulb. Nat Neurosci 10:631-639. CrossRef Medline

Wachowiak M, Cohen LB (2001) Representation of odorants by receptor neuron input to the mouse olfactory bulb. Neuron 32:723-735. CrossRef Medline

Wachowiak M, McGann JP, Heyward PM, Shao Z, Puche AC, Shipley MT (2005) Inhibition of olfactory receptor neuron input to olfactory bulb glomeruli mediated by suppression of presynaptic calcium influx. J Neurophysiol 94:2700-2712. CrossRef Medline

Wachowiak M, Economo MN, Díaz-Quesada M, Brunert D, Wesson DW, White JA, Rothermel M (2013) Optical dissection of odor information processing in vivo using GCaMPs expressed in specified cell types of the olfactory bulb. J Neurosci 33:5285-5300. CrossRef Medline

Wesson DW, Carey RM, Verhagen JV, Wachowiak M (2008) Rapid encoding and perception of novel odors in the rat. PLoS Biol 6:e82. CrossRef Medline

Whitesell JD, Sorensen KA, Jarvie BC, Hentges ST, Schoppa NE (2013) Interglomerular lateral inhibition targeted on external tufted cells in the olfactory bulb. J Neurosci 33:1552-1563. CrossRef Medline

Xiang Z, Prince DA (2003) Heterogeneous actions of serotonin on interneurons in rat visual cortex. J Neurophysiol 89:1278-1287. Medline

Zariwala HA, Borghuis BG, Hoogland TM, Madisen L, Tian L, De Zeeuw CI, Zeng H, Looger LL, Svoboda K, Chen TW (2012) A Cre-dependent GCaMP3 reporter mouse for neuronal imaging in vivo. J Neurosci 32: 3131-3141. CrossRef Medline

Zeitzer JM (2013) Control of sleep and wakefulness in health and disease. Prog Mol Biol Transl Sci 119:137-154. CrossRef Medline

Zhang WQ, Smolik CM, Barba-Escobedo PA, Gamez M, Sanchez JJ, Javors MA, Daws LC, Gould GG (2015) Acute dietary tryptophan manipulation differentially alters social behavior, brain serotonin and plasma corticosterone in three inbred mouse strains. Neuropharmacology 90:1-8. CrossRef Medline 